\title{
Environmental conditions of E Iberia's Early Triassic: an Earth example for understanding the habitability of ancient Mars
}

\author{
${ }^{1}$ Departamento de Estratigrafía-Universidad Complutense de Madrid C/ José Antonio Novais 2, 28040-Madrid, Spain; *Corresponding \\ author,E-mail:abgalan@ucm.es \\ ${ }^{2}$ Instituto de Geociencias-IGEO (CSIC,UCM) C/ Severo Ochoa 7, Edificio entre pabellones 7-8, Facultad de Medicina UCM, 28040-Madrid, Spain
}

(Received: January 23, 2017; Revised accepted: August 24, 2017)

http://dx.doi.org/10.18814/epiiugs/2018/v41i1/018004

During the Early Triassic, harsh environmental conditions delayed the biotic recovery after the end-Permian life crisis, which is generally related to the massive eruptive event of the Siberian traps. The scarcity of the fossil record in many areas of the Earth following this global crisis has been mainly attributed to arid and acid palaeoenvironmental conditions. In the Iberian Peninsula, extensive aeolian and braided fluvial paleoenvironments have been identified, and the presence of secondary minerals, such as kaolinite and aluminium-phosphate-sulfate (APS), has been associated with acid meteoric waters. On Mars, many of these features, such as aeolian facies and minerals like jarosite or hematite, related to acid ground water alteration products, have been previously described on Meridiani Planum. During the Late Noachian, the possible occurrence of liquid water and warm conditions have been reported, being one of the most favourable periods for life development on Mars. However, an increase in aridity and acidity during the Late Noachian-Early Hesperian (probably related to the Tharsis volcanism), together with the internal switches that could have provoked inefficient water recycling, may have hampered the appearance and/or development of favourable habitability conditions on this planet. Therefore, the comparison of extreme palaeoenvironmental conditions of the Early Triassic on Earth with data from Meridiani Planum can sheds some light on the study of habitability on ancient Mars.

\section{Introduction}

One of the main goals of Mars exploration and research is to detect and recognize signs, or biomarkers, of extinct or extant life. A first step is to understand the factors controlling past and present Mars habitability and their variation in space and time. Habitability is commonly understood as "the potential of an environment (past or present) to support life of any kind" (Steele et al., 2005). Considering the only known example of our planet, the concept is based not only on the existence in the system of carbon compounds and liquid water, but also on whether appropriate environmental conditions are available to support life, even if life does not currently exist (Javaux and Dehant, 2010). Further information about habitability and Mars can be found in Bishop et al. (2004), Knoll and Grotzinger (2006), Martínez-Frías et al. (2007), Gómez et al. (2012), Bishop et al. (2013), Jaumann et al. (2013), Michalski et al. (2013), Westall et al. (2013), Bridges (2014), Bridges et al. (2015), Cockell (2014), Léveillé et al. (2014), MartínezFrías (2014), Preston and Dartnell (2014), Stromberg et al. (2014), Greenberger et al. (2015), Grotzinger et al. (2015), Rölin et al. (2015) and Schwenzer et al. (2016) among others.

As well described by Rölin et al. (2015), mineralogical studies of a planet reflect its past and present environmental conditions and allow for a habitability assessment by comparison with the habitability of Earth under harsh conditions. Hence the significance of Earth analogues such us the one presented in this study, which compares sedimentoloical, mineralogical, and geochemical features of the Early Triassic period with those of some well-known areas of Mars like Meridiani Planunm, in order to further understand their significance on the habitability conditions of both planets.

According to the findings of Karunatillake et al. (2014), sulphatebearing strata existing across Late-Noachian to Amazonian eons point to a key role of sulphates in the acidity and salinity of Martian palaeofluids and consequently in this planet's habitability. Similarly, it is well known that phosphate is a vital nutrient for life. Thus, this element should also be considered in the search for signs of life, past or present, on Mars. In this regard, it is important to stress that the amorphous fraction of Martian soils seems also to be rich in phosphate (Tu et al., 2014).

When looking for a comparable scenario on Earth, with environmental conditions related to life crisis, the Permian-Triassic (P-T) transition stands out as a very likely analogue. During Earth history, life has experienced harsh periods in which habitability conditions were unsuitable for sustaining it, producing severe life crises. The most important was the Permian-Triassic biotic crisis in which life was almost erased from both marine and terrestrial ecosystems and had as a result one of the longest recovery periods (Kozur and Weems, 2011; Benton and Newell, 2014). This crisis was probably triggered by a combination of different causes rather than a single event (Berner, 2002; Galfetti et al., 2007). The subsequent scenarios were proba- 
bly a consequence of the voluminous Siberian Traps eruptions, including $\mathrm{CO}_{2}$ emissions and methane release which induced global warming (Wignall, 2001; Algeo et al., 2011; Benton and Newell, 2014). The activity of the Siberian Traps probably continued into Early Triassic times (Nikishin et al., 2002; Payne and Kump, 2007) enhancing greenhouse climate conditions and acidification that played an important role in the biotic crises (Montañez et al., 2007; Romano et al., 2013; Benton and Newell, 2014; Sephton et al., 2015) and even in the later recovery of ecosystems during the Early Triassic (Kozur and Weems, 2011). All these environmental perturbations imprint their mark in the geological record by the scarcity of fossils and other signs of life such as the coal gap in the continental settings and a chert gap in the oceans (Kidder and Worsley, 2004; Woods, 2005; Knoll et al., 2007; Chen and Benton, 2012). Moreover, the environmental damage has been also recorded by changes in continental sedimentary systems increasing the eolian deposits (López-Gómez et al., 2005; Smith and Botha, 2005; Bourquin et al., 2011), and in geochemical markers such as Sr, $\mathrm{S}, \mathrm{C}$ and $\mathrm{O}$ isotopic shifts along Permian-Triassic Boundary (Korte et al., 2003; Maruoka et al., 2003; Corsetti et al., 2005; Payne and Kump, 2007; Prokoph et al., 2008; Kearsey et al., 2009; Romano et al., 2013; Sanson-Barrera et al., 2015; Cui et al., 2017).

Bearing these aspects in mind, and despite of the differences in the ages and lengths of the periods compared, here we present mineralogical and geochemical features from several palaeoenvironmentallysignificant Early Triassic stratigraphic sections of the eastern Iberia Peninsula (Figs. 1a-c) that are similar to those described in Meridiani Planum (Mars) during the Late Noachian-Early Hesperian.

The aim of this paper is to compare the palaeoenvironments of
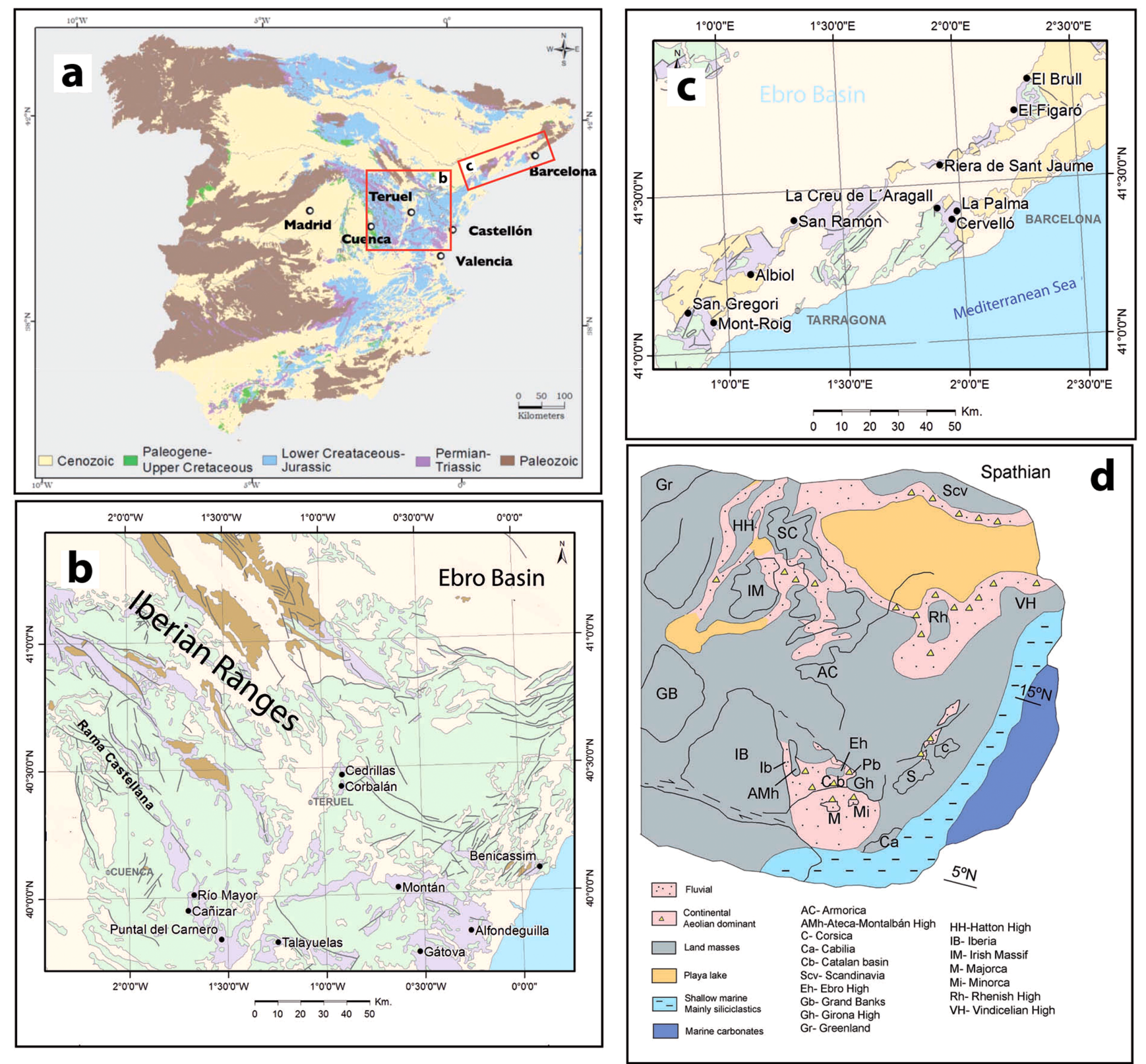

Figure 1. (a) Study area located in the Eastern part of the Iberian Peninsula. (b and c) Location of the stratigraphic sections sampled in the Permian-Triassic outcrops from Iberian and Catalan Coastal Ranges. (d) paleogeographic reconstruction of the western Tethys and the rift basins formed during the break up of Pangea during the late-Early Triassic Times (Modified from Borruel-Abadia et al., 2015). 
these sites in order to pinpoint the key factors that controlled their habitability conditions. Since the Early Triassic period was a crucial moment for the evolution of life on Earth after the P-T crises (Benton, 2016), the multidisciplinary approach of this work provides a relevant example of the factors that may have been crucial for hindering the development of habitable settings on Mars, such as $\mathrm{pH}$ of fluids, aridity, volcanism or tectonics. For this purpose, we consider the variations in extreme conditions during this particular period on Earth, in order to better understand the palaeoenvironmental and habitability changes produced in Meridiani Martian regions. Although there are clear differences between both sites and periods such as age (247 Myr vs. 3.7 Gyr) (Hynek and Phillips, 2008; López-Gómez et al., 2012) or atmospheric composition (oxic vs. anoxic) (Berner, 2006; Lammer et al., 2013), nevertheless they present strikingly similar, sedimentary features, and mineralogical associations. Thus, this paper may provide a step forward in the understanding of the causes that led to a life recovery in the Triassic of the Earth and that could have prevented its appearance and/or development on early Mars.

\section{Location and Geological Setting of the Triassic Outcrops}

At the end of the Palaeozoic, the early break-up of the Pangea supercontinent created new rift basins in the western Tethys (e.g., Germany, France, Iberia, and Morocco, among others) (Fig. 1d). During Early-Middle Permian times, in the eastern part of the Iberian Plate two different rift basins, the Iberian and Catalan basins, started to develop resulting and evolving through successive tectonic pulses marked by unconformities in the sedimentary record (Figs. 1d and 2) (Marzo, 1980; Arche and López-Gómez, 1999b; Arche et al., 2004;). One of these unconformities appears between middle-Upper Permian and Lower Triassic sediments, thus the P-T boundary (PTB) is not recorded in this area. These basins were filled with continental deposits from the Early Permian to late Lower Triassic, and covered by marine sediments in the late Middle Triassic due to the Tethys transgression from the East (Arche et al., 2004; Escudero-Mozo et al., 2015). Later, during the compressive stages of the Alpine orogeny, these basins were tectonically inverted to form the present day Iberian and Catalan Coastal Ranges (Arche and López-Gómez, 1996; López-Gómez et al., 2002). The data presented here were obtained from 20 sections taken from the two latter ranges (Figs. $1 \mathrm{~b}$ and c). Samples are nonmarine siliciclastic rocks collected from two Early-Middle Triassic stratigraphic units, broadly named Lower and Upper units in both ranges, according to their age and sedimentological features (Fig. 2). These units from base to top are called Cañizar and Eslida Formations (Fm.), in the Iberian Ranges (López-Gómez and Arche, 1992a), and Areniscas de Prades Inferior and Areniscas de Prades Superior Units (and their lateral equivalents), from base to top respectively in the Catalan Coastal Ranges (Marzo, 1980; Galán-Abellán et al., 2013a).

The Lower Unit in the Iberian Ranges (Cañizar Fm.) mainly consists of red sandstones deposited by fluvial braided systems and minor aeolian sediments. These latter sediments are more frequent westwards being dominant in some areas of the Catalan Ranges (Marzo, 1986, López-Gómez et al., 2012; Galán-Abellán et al., 2013a). In the Iberian Ranges this Lower Unit is divided into 6 subunits separated by
7 major boundary surfaces representing several tectonic pulses and sedimentary interruptions (López-Gómez et al., 2012). Its most remarkable feature is a missing fossil record until the top of this unit (subunit 5) with the occurrence of organic matter remains, incipient palaeosols and tetrapod trace marks (Gand et al., 2010; Galán-Abellán, 2011) (Fig. 2). Although not all of these subunits and interruptions are clearly constrained in the Catalan Ranges, however there is an equivalence between the Iberian and Catalan units in age, sedimentological features and the recovery patterns, so a probably coeval late OlenekianAnisian tectonic activity is considered in the Catalan Basin (GalánAbellán, 2011; Galán-Abellán et al., 2013a; Borruel-Abadía et al., 2015). Pollen assemblages and magnetostratigraphy studies indicate an early Anisian age for the upper part of these units whereas the age of their lower part has been estimated as Olenekian (Doubinger el al., 1990; Dinarès-Turell et al., 2005; López-Gómez et al., 2012). This Lower Unit is frequently separated from the Upper one by an interruption in the sedimentation (López-Gómez and Arche, 1992a) (Fig. 2).

The Upper Unit only appears on the eastern side of the Iberian Ranges (Eslida Fm.) and in all the Catalan Ranges (Areniscas de Prades Superior Unit) showing variable thickness in both cases. Its thickness is conditioned by different subsidence rates across the study area due to different subsidence rates (Vargas et al., 2009). Contact with the upper transitional and marine units of Röt and Muschelkalk facies is gradual (López-Gómez and Arche, 1992b; Marzo, 1980). The Upper Unit consists of red sandstones, siltstones and minor proportions of mudstones, deposited by braided and punctate meandering fluvial systems (Arche and López-Gómez, 1999a). This unit is also characterized by the presence of incipient palaeosols with some calcareous nodules, punctual pseudocubic molds of halite and, more abundant and diverse fossil remains such as pollen and flora assemblages, insects and tetrapod footprints of middle Anisian age (Boulouard and Viallard, 1982; Béthoux et al., 2009; Gand et al., 2010; Galán-Abellán, 2011).

\section{Main Characteristics of Lower Triassic Rocks in E Iberia}

During the Permian-Triassic transition, the combination of several palaeoenvironmental factors gave rise to the most significant biotic extinction of Earth's history, erasing almost all life both marine and continental (Erwin, 2006; Algeo et al., 2011; Benton and Newell, 2014; Chen et al., 2014; Shen et al., 2014; Sephton et al., 2015). The consequences of these drastic conditions on land can be observed in Early-Middle Triassic outcrops in the eastern Iberia Peninsula. Studies in this area have focused on identifying the effects of the palaeoenvironmental conditions of the Permian-Triassic transition and its aftermath on subsequent biotic recovery. These studies have covered several fields like sedimentology, palaeontology, mineralogy and geochemistry. By combining these data, a more accurate picture of the habitability of Early-Middle Triassic times has been described (Gand et al., 2010; López-Gómez et al., 2012; De la Horra et al., 2012; Galán-Abellán et al., 2013a, b, c; Borruel-Abadía et al., 2014, 2015).

\section{Sedimentology and Palaeoclimate}

Sedimentological studies conducted on non-marine Early-Middle 


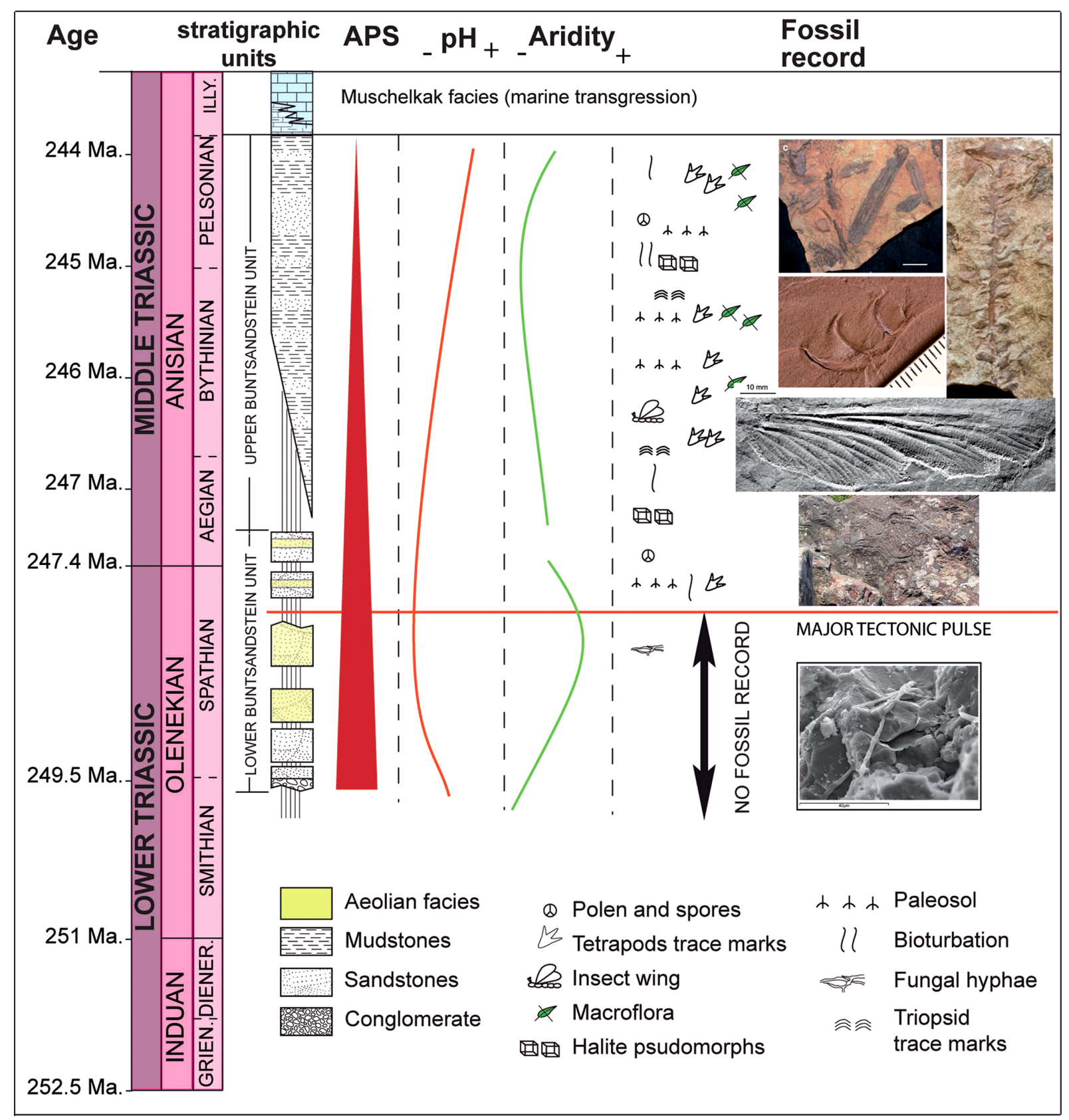

Figure 2. Changes of different palaeoenvironmental indicator such as APS mineral abundance, acidity, aridity and the fossil content found in the East Part of Iberian Triassic outcrops, along the Lower and Middle Triassic. Notice that the most significant changes are related to the major boundary surface 5, located within the upper part of the Lower units, associated with a regional tectonic pulse. All the data shown in this figure are included in Galán-Abellán (2011). For more information about those data, see the section "Main characteristics of Lower Triassic rocks in E Iberia" of the text and the references cited therein.

Triassic sandstones (the so-called Buntsandstain facies) in the eastern Iberia Peninsula have served to detect a change from dry conditions, marked by the occurrence of aeolian facies and braided fluvial systems during the deposition of Lower Triassic sediments, towards generally more humid conditions, characterized by braided and occasionally meandering fluvial systems with flood plains described in early Middle Triassic deposits (Bourquin et al., 2011; López-Gómez et al., 2012: Galán-Abellán et al., 2013a; Borruel-Abadía et al., 2015). This change broadly corresponds to the transition from the upper part of the Lower Unit to the Upper Unit in the studied rocks. The upwards disappearance of aeolian facies, the change in fluvial style from braided to meandering, and the fine grains present in overbank facies have been taken to indicate the presence of a vegetation that retained fine grained particles in soil (Arche and López-Gómez, 2005; Davies and Gibling, 2010). The occurrence of incipient palaeosols in the Upper Unit indicates a seasonal climate with subhumid stages (Galán-Abellán, 2011; Borruel-Abadía et al., 2015). These arid conditions are also influenced by the paleogeographical relief being more extensive eastwards accordingly with the predominant paleowinds directions and the latitudinal subarid zones distribution in west Tethys area (Central Europe) (Fluteau et al., 2003; Bourquin et al., 2011; Galán-Abellán et al., 2013a; Borruel-Abadía et al., 2015). 


\section{Mineralogy and Geochemistry}

The Lower Unit is mainly composed of quartz, feldspars, lithic fragments and micas as major detrital phases, and Fe-oxides (illmenite, rutile), tourmaline, zircon, apatite, xenotime, and monazite as minority phases. Besides, early diagenetic minerals like aluminium-phosphatesulphate (APS) minerals and hematite have also been described. Fine grained sediments (mudstones and siltstones) are composed mainly of illite and minor amounts of kaolinite, but they are very rare along this unit, (Galán-Abellán, 2011; Galán-Abellán et al., 2013b).

The Upper Unit sandstones are similar in mineralogical composition to those of the Lower Unit and vary mostly in their proportions of major detrital phases; the Upper Unit contains less quartz and greater amounts of feldspar and mica and more carbonate cements in the Catalan Basin (Galán-Abellán, 2011; Galán-Abellán et al., 2013b, c). As early-diagenetic phases, lower quantities of APS minerals are observed than in the Lower Unit (Galán-Abellán et al., 2013b, c; Borruel-Abadía et al., 2016). In addition, siltstones and mudstones are more common in this unit and they are mainly composed of illite and kaolinite.

Although the mineral composition of Upper and Lower Units is very similar, there are some mineralogical and geochemical indicators that also reveal unfavourable conditions for the recovery of life during the Early Triassic. Petrographical and textural studies show that APS minerals and kaolinite occurred as early diagenetic phases, and Galán-Abellán et al. $(2013 b, c)$ considered their formation as a result of acid meteoric water circulation in the sediments. Kaolinite is more common towards the east sections and the Upper Unit and it is related to the feldspar replacement, whereas the APS minerals predominantly appear in the Lower Unit and their occurrence decreases upwards into the Upper Unit (Galán-Abellán et al., 2013c). The APS minerals are a solid solution between phosphate-sulphates with $\mathrm{Al}, \mathrm{Sr}$ and $\mathrm{Ca}$ as major elements and minor amounts of REE predominantly LREEs such as La, Ce and Nd (Galán-Abellán, 2013b). Sulfur and strontium isotopic signatures point to marine and volcanic aerosols as likely sources, combined to dissolution of pre-existing sulphides like pyrite, mainly in the Lower Unit (Galán-Abellán et al., 2013c). The combination of acid rain derived from volcanic aerosols and pyrite oxidation could have enhance the acidity of meteoric waters causing the dissolution of detritial minerals like feldspars and phosphates (monazite, xenotime and apatite) which are more soluble under acid conditions (Guidry and Mackenzie 2003) and forming the APS (Galán-Abellán et al., 2013c). These acidic conditions during the Early Triassic would have progressively declined through Middle Triassic deposits, which is supported by the quantification of APS phases (Borruel-Abadía et al., 2016). In addition, the increase of kaolinite occurrence would be related to the decrease of the aridity towards a more seasonal climate.

Nonetheless, it is important to notice that the strontium isotopes have a strong radiogenic influence from the source areas that also mark a change in provenance between Lower and Upper Units (Galán-Abellán, 2011; Galán-Abellán et al., 2013c), which is in concordance with other mineralogical and isotopic data such as $\mathrm{Pb}-\mathrm{Pb}$ isotopes in detrital zircons, that point to a possible change in the source areas and provenance of the lower and upper parts of the Lower Unit, probably related to the tectonic pulses as consequence of Pangea Break up (Sánchez-Martínez et al., 2012). These changes could have triggered shifts in the water circulation and in its oxygenation and a decrease in the acidity conditions, in agreement with the APS minerals decrease and the reappearance of life sings (Galán-Abellán et al., 2013c; BorruelAbadía et al., 2016).

\section{Fossil Record and Habitability Conditions}

Sedimentological, mineralogical and geochemical data all point to arid and acid environmental conditions during the Early Triassic progressing to more seasonal and humid conditions along with an increasing $\mathrm{pH}$ of meteoric waters during the Middle Triassic (LópezGómez et al., 2012; Galán-Abellán et al., 2013c; Borruel-Abadía et al., 2015). The appearance of the first fossil record in this area is consistent with this palaeoclimate change (Fig. 2). In the Lower Unit, fossil remains do not appear until the uppermost part where undetermined organic matter and the first trace marks of Mesozoic tetrapods of the Iberia Peninsula have been described (Gand et al., 2010; Galán-Abellán, 2011). In contrast, the Upper Unit shows incipient palaeosols with carbonate cements and nodules, and the macro- and micro-flora record of this area correlates with the increase in $\mathrm{pH}$ conditions observed, marking the emergence of more habitable conditions for life (Fig. 2) (GalánAbellán, 2011; López-Gómez et al., 2012; Borruel-Abadía et al., 2014; Borruel-Abadía et al., 2015).

Collectively, these findings indicate that during Early Triassic times, the harsh arid and acid palaeoenvironmental conditions prevailing on land in the western Tethys prevented the development of more favourable conditions and delayed biotic recovery after the end Permian life crisis. The factors promoting a shift towards an environmental context that was conducive to widespread life are still under debate (Benton and Newell, 2014). However, such a setting was probably the outcome of major tectonic pulses that modified the paleorelief distribution in this area, and produced important changes in the main fluvial systems supplying more oxygenated waters and nutrients, and opening of new faunal corridors (Galán-Abellán, 2011; López-Gómez et al., 2012; Sánchez-Martínez et al., 2012; Borruel-Abadía et al., 2015).

\section{Meridiani Planum, Mars}

The geological history of Mars is still under discussion despite new data from orbital and in situ observations have shed some light on this question. Although geological times and conditions are not comparable, certain Triassic settings on Earth, such as Watchet Bay (UK) (Schwenzer et al., 2016), have been considered possible Martian analogues of Gale crater, based on the most recent data from the Mars Science Laboratory, Curiosity. However, the Early Triassic conditions described in the eastern part of the Iberian Peninsula (see previous section) may have important similarities with those suggested by available data for the Meridiani Planum region (Figs. 3a and b). Since 2004, the rover Opportunity has examined outcrops of the craters Eagle, Fram, Endurance, Erebus, Victoria, Sta. Maria and Endeavour and provided information on the sedimentology, mineralogy and geochemistry of these outcrops.

\section{Sedimentary and Stratigraphic Observations}

Sedimentary and stratigraphic studies examining exposed bedrock 


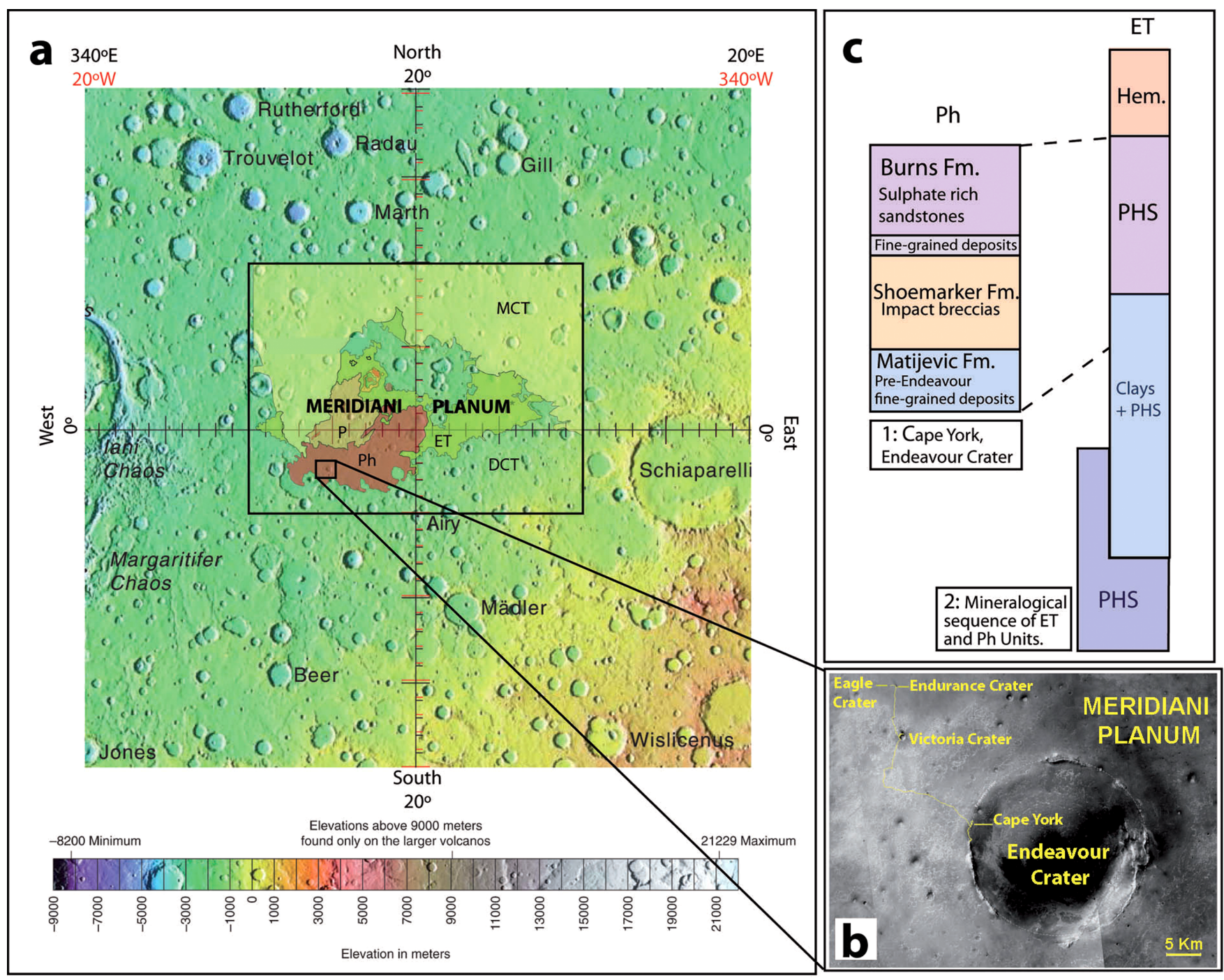

Figure 3. (a) Location of Meridiani Planum area. The geological map, modified from Arvidson et al. (2003), has been superimposed to the high resolution topographic shaded relief map from the Mars Orbiter Laser Altimeter (MOLA) on NASA's Mars Global Surveyor (MGS) spacecraft. http://astrogeology.usgs.gov/search/details/Docs/Globes/i2782 sh1/pdf. DCT is the oldest unit exposed and corresponds to Noachian dissected cratered terrain. Unit ET is the Etched unit that overlies the DCT unit. It corresponds to a complex set of landforms that show significant aeolian erosion. Units Ph and P overlie ET. Unit Ph is a hematite bearing plains deposit and Unit P is a lateral facies variation. All this units are covered by mantled cratered terrain unit or Unit MCT, which has been partially stripped by aeolian processes to expose underlying materials. (b) Transverse map of Meridiani Planum region explored by NASA's Mars Exploration Rover Opportunity. The base image for the map is a mosaic of images taken by the Context Camera on NASA's Mars Reconnaissance Orbiter. NASA/JPL-Caltech/MSSS/ NMMNHS. http://www.jpl.nasa.gov/spaceimages/details.php?id=PIA19154 (c) Possible relationship between two areas of Meridiani Planum and its materials based on their mineralogical compositions proposed by Flahaut et al. (2015). 1: Cape York stratigraphic succession at Endeavour Crater (Arvidson et al., 2014). Matijevic formation corresponds to fluvial, eolian, distal impact or explosive volcanic layered, finegrained deposits. The aqueous alteration of these deposits generated clay minerals like smectite, and hydrated silica-rich materials. The Shoemaker formation is formed by breccias probably emplaced by the Endeavour impact. Burns Formation is constituted by sulphate-rich sandstones equivalent to those previously observed by the Opportunity rover at the Endurance Crater (Grotzinger et al., 2005). 2: Interpretive cross-section of the mineralogical sequence within the ET and Ph units, modified from Flahaut et al. (2015). Sulfate rich bottom unit, mainly composed of kieserite + PHS. (PHS: Polyhydrated Sulfates), intermediate clay-enriched unit (Al-, Fe-rich smectites), an upper sulphate-rich unit composed of jarosite, gypsum, hematite and PHS, and the topmost hematite-rich lag deposit (Hem: Hematite).

in Meridiani Planum show several laterally continuous and stratigraphically correlated units (Edgar et al., 2012; Squyres et al., 2012; Arvidson et al., 2014; Flahaut et al., 2015). Sedimentary deposits composed of sulphates and clays are widely distributed across this zone suggesting a regional stratigraphic succession consisting of a sulphate-rich bottom unit (kieserite and polyhydrated sulphates), an intermediate clay-enriched unit (Fe and Al-rich smectites), and a topmost sulphate-rich unit (polyhydrated sulphates, jarosite, gypsum, hematite) (Fig. 3c) (Flahaut et al., 2015). The Al-rich smectite unit observed from orbit at the etched terrains could correspond to the fine grained deposits analysed by the Opportunity rover in the Matijevic formation at Cape York, on the rim of the Endeavour crater (Fig. 3c) 
(Wray et al., 2009; Arvidson et al., 2014; Flahaut et al., 2015). This clay layer separates the lower sulphate-rich from upper sulphate-rich unit, which is characterised by the occurrence of hematite, suggesting a different event with a different formation mechanism than for the lower sulphate unit (Arvidson et al., 2014; Flahaut et al., 2015). This upper sulphate unit can be also correlated with the Burns Formation analysed by Opportunity at different outcrops of the hematite-bearing plains and is the main unit considered in the present work (Fig. 3c) (Squyres et al., 2012).

The Burns Formation, exposed from $30-40 \mathrm{~cm}$ at Eagle crater to $7 \mathrm{~m}$ at Endurance crater, is divided into the units, Lower, Middle and Upper, which have been respectively interpreted as aeolian dune fields, aeolian sand sheets and interdunes/playas (Grotzinger et al., 2005). Sedimentary structures, facies associations and mean grain size distributions indicate their deposition by aeolian and locally subaqueous processes, recording a progressive increase in the influence of ground water and surface water during deposition. Water table fluctuations controlled facies and stratigraphic architecture, as well as subsequent diagenetic recrystalization (Grotzinger et al., 2005; Squyres et al., 2006). The contact between the Lower and Middle Units has been interpreted as a deflation surface. This irregular surface provides evidence that the Lower unit was lightly cemented by the time of scouring by a rise in the water table after dune formation (Grotzinger et al., 2005; Squyres and Knoll, 2005). In the sand sheet deposits of the Middle unit, the sediment may have been damp but the water table had not risen to the surface until the deposition of the uppermost part of the Upper unit (Grotzinger et al., 2005; McLennan et al., 2005). The uppermost unit of this formation exposed in Erebus crater can be correlated with the outcrops of the Victoria crater, indicating a higher stratigraphic position of the Victoria crater units.

The outcrops at Duck Bay (Victoria crater) are divided into three units, Lyell, Smith and Steno from bottom to top, and the total thickness exposed in this region is $15 \mathrm{~m}$ (Edgar et al., 2012). The Lyell, Smith and Steno units are also interpreted as aeolian dune fields, being part of a large sand sea with no evidence of processes involving water such as those described at the Eagle and Endurance craters (Edgar et al., 2012). Lyell and Smith are interpreted as having formed under the same dune package. However, the gradational contact between them, their lighter tone and the poorly preserved lamination upwards, indicate that the Smith unit is recrystallized. The base of the Steno unit is marked by an erosional contact, and was also formed in an aeolian depositional environment (Squyres et al., 2009; Hayes et al., 2011; Edgar et al., 2012).

Thus, the stratigraphic sequence of the explored outcrops of Meridiani Planum shows variation from dry to wet to dry conditions upwards through the units of the craters Eagle, Endurance, Erebus, Victoria and Endeavour. Layered sediments were emplaced by aeolian and aqueous processes probably formed at Meridiani with a local source area rather than being transported from a distant source (Squyres et al., 2006).

\section{Mineralogical Assemblages: Provenance and Diagenetic Processes}

The ancient sedimentary rocks of Burns Formation are mainly composed of evaporites and siliciclastic particles. Evaporite assem- blages have chemical constituents and relative abundances of these constituents that are not in equilibrium, indicative of reworking by wind and occasional surface water (Clark et al., 2005; McLennan et al., 2005; Squyres and Knoll, 2005).

So far, no observation has been made of non-reworked sediments that reveals the environmental conditions of the source area. The likely mechanism proposed is erosion from a pan of sulphate precipitates and fine grained siliciclastic particles formed through the chemical weathering of olivine basalts by acid ground waters and subsequent evaporation under arid conditions (Squyres et al., 2004; Grotzinger et al., 2005; McLennan et al., 2005; Squyres et al., 2006; Tosca and McLennan, 2006). However, in the absence of original source areas deposits, other scenarios such as acid sulphate weathering in a volcanic environment cannot be ruled out (McCollom and Hynek, 2005). The two major differences between these hypotheses are the sources of sediments and sulphur (exogenic or endogenic), and even a hybrid hypothesis evoking sulphur-rich volcanic ash reworked into aeolian material could also be possible (Hynek and Philips, 2008).

Mineralogical components inferred from the combination of Mössbauer and thermal emission infrared spectroscopy, geochemical analysis and Pancam images are a mixture of siliciclastic debris of basaltic provenance (pyroxene and traces of olivine) and its weathering products (possibly sheet silicates and Fe-bearing components dominated by $\mathrm{Fe}^{3+}$ ), evaporitic minerals predominantly $\mathrm{Mg}$-sulphates but also Ca-sulphates and Fe-sulphates (including jarosite), chlorides, and possibly secondary silica. Hematite occurs in the sand grains, cements, and in spherules. However, neither petrographic nor textural unequivocal evidence exists for any mineral identification (Christensen et al., 2004; Clark et al., 2005; McLennan et al., 2005).

Observed processes such as precipitation and recrystallization of cements or mineral dissolution recorded as moulds or spherules indicate a complex diagenetic history related to acid ground water flow (Herkenhoff et al., 2004; McLennan et al., 2005; Squyres et al., 2006; Squyres et al., 2009). Spherules of hematite, almost spherical and mainly showing uniform distributions, formed in stagnant or very slowly-moving ground waters that percolated though all the units (Lower, Middle and Upper) of the Burns Formation (Squyres and Knoll, 2005). Experimental studies have revealed that jarosite may have acted as the $\mathrm{Fe}$ source for Fe-oxides (Tosca et al., 2005; Tosca et al., 2008). However, the significant amounts of jarosite still present in the rock suggest that this process did not continue for long enough to transform of all the iron in the jarosite to oxides. Hence, the reaction either reached equilibrium or ceased due to water removal (Madden et al., 2004; Fernández-Remolar et al., 2005; McLennan et al., 2005; McLennan, 2012). In addition, Morris et al. (2005) proposed a terrestrial analogue for the spherule formation mechanism. These authors described the formation of tiny hematitic spherules related to acid hydrothermal ground water percolating through basalts in Hawaii, which seems close to Meridiani Planum conditions (acid waters and basaltic substrates) (Squyres and Knoll, 2005).

Another important digenetic feature of the Burns Formation is the presence of elongated voids in abundance but randomly distributed at both Eagle and Endurance crater, which have been described as the result of late-forming evaporitic mineral dissolution, perhaps Fe-, Mg-, Ca-chlorides (Squyres et al., 2004; McLennan et al., 2005). Besides, there are two generations of cements: a first one related to sediment 
lithification and a second generation formed through recrystallization around the spherules. Cement mineralogy is not well defined but probably comprises Fe-, Mg- and Ca-sulphates, chlorides, hematite, and amorphous silica (McLennan et al., 2005).

\section{Ancient Environmental Conditions}

The layered deposits of Meridiani Planum lie unconformably on Middle-Late Noachian cratered terrains. Besides, three dimensional analysis of stratigraphic horizons, mapping and a regional features approach have constrained the emplacement age of these deposits to the Late Noachian-Early Hesperian epoch (Hynek et al., 2002; Lane et al., 2003; Squyres and Knoll, 2005; Hynek and Philips, 2008; Edgar et al., 2012). Although the causes and mechanism are still poorly understood, there are several lines of evidence, including geomorphic and mineralogical, that show significant changes in the environmental conditions during Late Noachian-Early Hesperian times.

For the Late Noachian, evidence of surface and ground waters such as lakes, valley networks and karst landforms has been described in Meridiani and other regions of Mars (Grotzinger et al., 2005; Carr, 2006; Fasset and Head, 2008; Hynek and Philips, 2008; Flahaut et al., 2015). In addition, the presence of phyllosilicates points to episodically warm and wet conditions (Bibring et al., 2006; Carr and Head, 2010). The mechanism for this warming has been described as the addition to the atmosphere of greenhouse gases, like $\mathrm{SO}_{2}$ or $\mathrm{CH}_{4}$, due to insufficient amounts of $\mathrm{CO}_{2}$ or as large scale climate perturbations such as volcanism or meteorite impacts (Carr and Head, 2010; Ehlmann et al., 2011). At the end of the Noachian and beginning of the Hesperian a change occurred towards drier, cooler and more acidic environmental conditions, reflected by a mineralogical switch from dominant clay-rich exposures to sulphate-rich sedimentary rocks, a decrease in chemical weathering and erosion, and an emergent thick global cryosphere (Bibring et al., 2006; Carr and Head, 2010; Ehlmann et al., 2011).

Several surface processes have been related to the mineralogical and geochemical features observed in these rocks and to the findings of experimental models. These processes are mainly desiccation, acidification and oxidation and seem to be determined by the amount and composition of near-surface water and by arid conditions reflecting mineralogical changes (McLennan, 2012). Aeolian sedimentary structures are in agreement with arid conditions, which have been inferred for the presence of evaporitic minerals such as sulphates and chlorides (probably halite), and the presence of ferric iron is indicative of oxidizing conditions during deposition and diagenesis. Besides, ferrous iron oxidation produces a decrease of $\mathrm{pH}$ in the near-surface environment (McLennan, 2012).

Acid aqueous conditions have been linked to the presence of sulphate, specifically jarosite, and to hematite spherule formation (Klingelhöfer et al., 2004; Bibring et al., 2006; Tosca and McLennan, 2006; Murchie et al., 2009; Roach et al., 2010; McLennan, 2012). In addition, experimental data provided by Benison et al. (2008) suggest that features produced by sulphuric acid solutions are consistent with some landscapes observed on Mars including deep, narrow channels with steep walls. Thus, acid solutions could be possible sedimentological agents on Mars (Beatty et al., 1999; Williams and Phillips, 2001). The presence of Noachian $\mathrm{Fe} / \mathrm{Mg}$ clays and the absence of kaolinite in different areas of Meridiani suggest relatively higher $\mathrm{pH}$ conditions than those expected, however smectite formation could also correspond to the earliest stages of basalt weathering involving relatively small amounts of water (Nesbitt and Wilson, 1992; McLennan, 2012). Many authors examining the composition of Martian basalts have concluded that there must have been low water-rock interactions for the expected low $\mathrm{pH}$, otherwise chemical interactions would rapidly lead to circumneutral $\mathrm{pH}$ and consequently it would not be possible to sustain acidic conditions (Golden et al., 2005; Tosca et al., 2005; Hurowitz et al., 2005, 2006; Tosca and McLennan, 2006; McLennan, 2012). The low water-rock ratios are also supported by the alteration of olivine, but not of plagioclase, and the lack of evidence for significant Al mobility such as Al-sulphates, Al-hydroxides or clays (Hurowitz and McLennan, 2007). Therefore, the variation in $\mathrm{pH}$ reflects a balance between acid generation from added sulphur and evaporation, and buffering by weathering reactions (McLennan, 2012). Sulphate deposits and hematite concretions have been attributed to chemical weathering and acid ground water processes under arid conditions (Grotzinget et al., 2005; Knoll et al., 2005; McLennan et al., 2005; Squyres et al., 2006; Tosca and McLennan, 2006). The sulphate-rich sands of Meridiani cover several hundred thousand square kilometres in this and other areas of the Mars surface (Gendrin et al., 2005; Carr and Head, 2010), the presence of basalt sand grains like olivine, pyroxene and feldspar (Christensen and Ruff, 2004) as well as the broad occurrence of basalts and olivine basalts across equatorial and mid-latitude regions of Mars, suggest physical weathering as the dominant process during the exposure time of these sands (Bandfield, 2002; Hoefen et al., 2003; Christensen et al., 2004). In contrast, hematite has been detected only in a few places on Mars, Meridiani Planum being the largest (Squyres et al., 2006). Thus, chemical weathering and aqueous processes such as ground water diagenesis may represent localized brief phenomena in the history of Mars, at least at low- to mid-latitudes (Christensen et al., 2004; Wyatt, 2004; Knoll et al., 2005; Squyres et al., 2006; Hurowitz et al., 2010; Flahaut et al., 2015).

\section{Discussion}

Despite differences in the ages and duration of the periods examined here, a general comparison of the sedimentological, mineralogi$\mathrm{cal}$ and geochemical features of the non-marine Triassic sandstones of E Iberia and of the sedimentary layered deposits of Meridiani Planum reveals several similarities in palaeoenvironmental conditions and in their influence on habitability conditions (Table 1). As already mentioned, the Early Triassic and Late Noachian-Early Hesperian ages were characterized by conditions unfavourable for habitability as consequence of different factors. The main causes of these hazardous scenarios are related to aridity and acidity.

Aside from Iberia, arid conditions during Early Triassic times have been reported in other basins worldwide (Geluk and Rötilig, 1999; Péron et al., 2005; Durand, 2006; Preto et al., 2010; Bourquin et al., 2011) and have been also described for the Late Noachian on Mars (Carr and Head, 2010; Ehlmann et al., 2011). These arid conditions are consistent with the sedimentological features described in both the Lower Triassic Units of eastern Iberia and sedimentary layered deposits of Meridiani Planum (etched terrains and hematite-bearing plains). In both cases, sediments were deposited by aeolian and fluvial sys- 
Table 1. Summary of the main similarities and differences between Early Triassic at the East Iberia and Meridiani Planum during Early Martian

\begin{tabular}{|l|l|l|}
\hline & \multicolumn{1}{|c|}{ Earth } & \multicolumn{1}{|c|}{ Mars } \\
\hline $\begin{array}{l}\text { Age } \\
\text { Location }\end{array}$ & $\begin{array}{l}\text { Early-Middle Triassic } \\
\text { Eastern Iberian Peninsula } \\
\text { Iberian and Catalonian Ranges }\end{array}$ & $\begin{array}{l}\text { Late Noachian-Early Hesperian } \\
\text { Meridiani Planum's etched terrains and hematite-bearing plains } \\
\text { (Eagle, Victoria, Endurance and Endeavour craters) }\end{array}$ \\
\hline Depositional environment & $\begin{array}{l}\text { Aeolian and fluvial braided systems } \\
\text { (Lower Units) }\end{array}$ & $\begin{array}{l}\text { Aeolian and interdune systems (Burns Formation; Lyel, Smith and } \\
\text { Steno Units) (Grotzinger et al., 2005; Hayes et al., 2011) }\end{array}$ \\
\hline Petrology provenance & $\begin{array}{l}\text { Igneous rock alteration: average upper crust } \\
\text { composition. }\end{array}$ & $\begin{array}{l}\text { Basalt and olivine basalt alteration (Christensen et al., 2004; } \\
\text { Klingelhöfer et al., 2004) }\end{array}$ \\
\hline Mineralogy & $\begin{array}{l}\text { Quartz, K-feldspar, micas, turmaline, Fe-Oxides, } \\
\text { APS, apatite, xenotime, monazite, zircon }\end{array}$ & $\begin{array}{l}\text { Ca- and Mg-sulphates, Fe-Sulphate (jarosite), Mg- Fe- and Al-clays, } \\
\text { glass, feldspar, sheet silicates, hematite, olivine, pyroxene, pla- } \\
\text { gioclase and phosphates (Christensen et al., 2004; Dyar et al., 2014) }\end{array}$ \\
\hline Habitability conditions & $\begin{array}{l}\text { Warm, arid climate } \\
\text { Low pH waters } \\
\text { Volcanism outgassing }\end{array}$ & $\begin{array}{l}\text { Cold, arid climate } \\
\text { Low pH waters } \\
\text { Volcanism outgassing }\end{array}$ \\
\hline Tectonic setting & $\begin{array}{l}\text { Major tectonic pulses related to Pangea break } \\
\text { ups. }\end{array}$ & $\begin{array}{l}\text { Internal dynamo ceasing and heat flow reduction (Langlais et al., } \\
\text { 2012; Ruiz, 2014). }\end{array}$ \\
\hline
\end{tabular}

tems, but their distributions and dominant deposits differ. In Iberia, fluvial structures predominate over aeolian forms, which are more common through the East (López-Gómez et al., 2012; Galán-Abellán et al., 2013a). In contrast, in Meridiani Planum, aeolian reworking is the predominant process although there is evidence of ground and superficial waters such as valley networks and karst landforms (McLennan, 2012; Flahaut et al., 2015) (Fig. 4).

The most remarkable difference between the two arid settings is that during the Early Triassic the climate was dry and warm whereas the Late Noachian experienced a cold, arid climate only interrupted by a short period of warmer and wetter conditions which allowed the presence of liquid surface water (Ehlmann et al., 2011; Benton and Newell, 2014). On Earth, the extremely high temperatures recorded were the consequence of a rise in greenhouse gases like $\mathrm{CO}_{2}$ and $\mathrm{CH}_{4}$ into the atmosphere (Benton and Newell, 2014). On Mars, the atmosphere must have had a greater $\mathrm{CO}_{2}$ pressure than the present and also trace gases such as $\mathrm{CH}_{4}, \mathrm{NH}_{3}$ or $\mathrm{SO}_{2}$ to produce the necessary pressure and temperature to sustain surface liquid water, probably driven by volcanism degasification (Johnson et al., 2008). In addition, changes in orbital and obliquity parameters could have also prompted the sporadic presence of surface liquid water (Squyres and Kasting, 1994; Ehlmann et al., 2011). Liquid water circulation led to the alteration of parent rocks producing detrital material and mineral dissolution that would later precipitate out as secondary minerals by evaporation.

The source areas of the detrital Iberian Triassic units have been located towards the northwest of the Variscan axial zone and their mineralogical and geochemical composition corresponds to typical upper crust values (Arche and López-Gómez, 1999b; López-Gómez et al., 2012; Sánchez-Martínez et al., 2012). On the contrary, the source areas of the mixed silicilastic-sulphate layered deposits of Mars have not been yet localized. However, their mineralogy inferred from Martian data points to aeolian reworked grains resulting from physical and chemical alteration of olivine basalts in a dirty playa, a volcanic environment or even a combination of both (McCollom and Hynek, 2005; Squyres et al., 2006). This different provenance gave rise to differences in the mineralogy of the two regions, as described in the previous sections, but in cases such as those of APS minerals or jarosite formation, similar conditions were required, namely acid water flow leading to acidity, which is the second key feature shared by these two scenarios.

In Triassic sandstones, APS and kaolinite formation is the consequence of acid meteoric water flow (Galán-Abellán et al., 2013b, c). In Meridiani Planum, the identification of Fe-sulphate (jarosite) is also unequivocal evidence of low $\mathrm{pH}$ conditions (Klingelhöfer et al., 2004). In addition, arid conditions would have favoured the evaporation of waters and precipitation of other evaporitic minerals such as Ca-sulphate and chlorides, probably gypsum and halite (Bridges and Grady, 1999; Christensen et al., 2004; Clark et al., 2005). Although halite pseudocubic moulds have been described in some samples of the Upper Triassic Unit, no direct evidence of these phases has been described in the Iberian samples (Galán-Abellán, 2011). On the other hand, predominant arid conditions prompted the physical weathering prevailing during the Early Triassic and Late Noachian-Early Hesperian over chemical weathering. However, chemical weathering promoted by acid water action on fresh rocks plays an important role in the mineral neoformation of secondary phases and cements (Squyres et al., 2006; Carr and Head, 2010; Galán-Abellán et al., 2013b). In fact, a change in weathering conditions has been observed from the Early to Middle Triassic, as well as from the Early Noachian to Late Noachian-Early Hesperian.

Weathering mechanisms evolved under extreme warm, dry conditions, from detrital feldspar and phosphate dissolution by acid waters and APS precipitation during the Early Triassic, to a higher circumneutral $\mathrm{pH}$, favouring carbonate formation and illite clays, in the Middle Triassic. It is coherent with a less warm and more humid climate during the deposition of upper units in the Middle Triassic (GalánAbellán, 2011; Galán-Abellán et al., 2013b; Borruel-Abadía et al., 2015).

A similar change but with an inverse trend took place during the Noachian. This period is characterised by the presence of phyllosilicates formed by the aqueous alteration of basalts. Dilution of acids and the prolonged existence of surface aqueous conditions favoured the local neutralization of acid waters and deposition of clay minerals (Zolotov and Mironenko, 2007; Carr and Head, 2010). This may have been induced by surface liquid water under warmer conditions during the Late Noachian (Squyres and Kasting, 1994; Carter et al., 2015). In the Late Noachian, weathering rates decreased and short-term alter- 

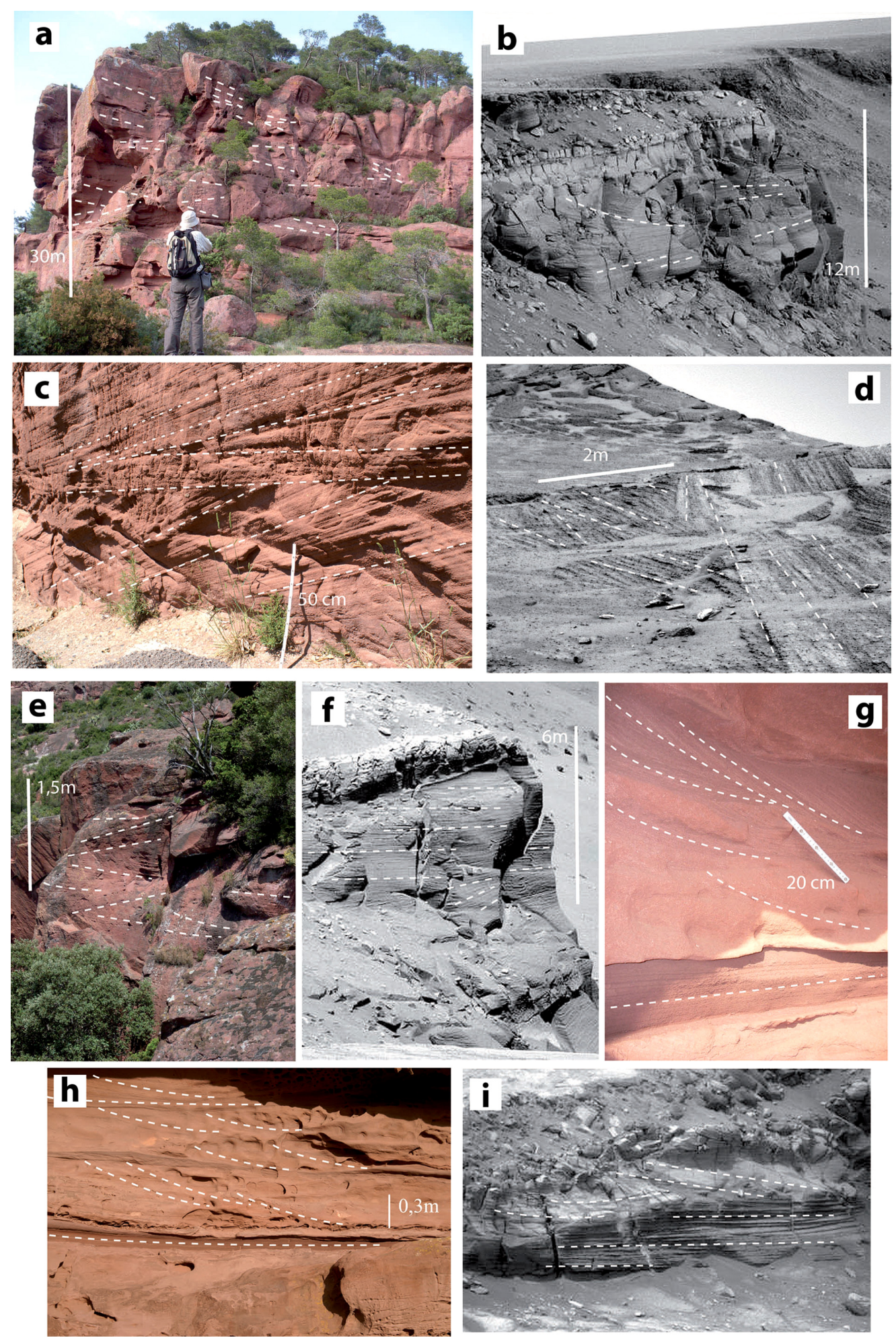

Figure 4. Comparison of different field structures form Iberian Triassic and Martian outcrops. Notice the similar cross-bedding stratification interpreted as aeolian dunes and interdunes structures, in both sites. (a) General view of the Lower Triassic Unit from San Gregory section. (b) Cape St. Vicent, Victoria Crater. Image 1P231788549EFF820TP2417L6M1.JPG acquired on sol 1167 using Opportunity panoramic camera (Pancam). (c) Middle part of the Lower Triassic Unit from Mont Roig section. (d) Contact between Lower and Middle part of the Burns Formation from the Endurance crater (Grotzinger et al., 2005). Image 1P153661186EFF37MIP2270L5M1.JPG acquired on sol 287 using Opportunity panoramic camera (Pancam) commanded to use Filter 5 (535 nm). (e) Upper Part of the Lower Triassic Unit from Mont Roig section. (f) Cape Desire, Victoria Crater. Image 1P222554139EFF78DYP2568L6M1.JPG acquired on Sol 1063 by Opportunity Pancam camera. ( $g$ and $h$ ) Details of an interdune-dune contact from the middle part of Lower Triassic unit, St. Gregori section. (i) Contact between planar and cross-bedding stratification of a target called "Paolo's Pan" in the surroundings of Victoria Crater. Mosaic of images acquired on sol 1360 with the panoramic camera and calibrated the panoramic camera by taking images in darkness 1 P248922687EFF8788P2405R2M1.JPG 
ation episodes ceased due to freezing or evaporation under dry and cold conditions prompting the formation of amorphous silica, $\mathrm{Fe}^{3+}$ oxy-hydroxides, and $\mathrm{Mg}$-, Fe- and Ca-sulphates (Zolotov and Mironenko, 2007). Besides, the presence of primary minerals like olivine indicate occasionally acid and limited low water-rock alteration extending into the Early Hesperian (Tosca et al., 2005; Carr and Head, 2010).

The possible causes of these changes and their implications for the development of habitability conditions are discussed below. A hydrothermal influence has been proposed for both settings related to APS formation in Early Triassic sandstones (Marfil et al., 2013) and clay occurrence on early Mars (Ehlmann et al., 2011). However, textural relationships between APS and surrounding minerals seem to indicate an early diagenetic origin for these Triassic phases (Galán-Abellán et al., 2013b), and mineral assemblages and the absence of high temperature minerals argue against a hydrothermal alteration mechanism on Mars (Carter et al., 2015; Flahaut et al., 2015). Accordingly, secondary mineralogy like sulphates of the two study sites is probably the consequence of acid weathering processes.

Volcanism and sulphide oxidation could have induced the acid conditions of both settings. Although there is so far no sedimentological or petrographical evidence of cinerites in the E Iberia study area, acid rain as consequence of Early Triassic volcanism has been proposed as a possible source of acid conditions. Furthermore, geochemical isotopic analyses have suggested a possible volcanic origin for the sulphur of APS minerals (Galán-Abellán et al., 2013b, c). On Mars, $\mathrm{CO}_{2}, \mathrm{SO}_{2}$, and $\mathrm{H}_{2} \mathrm{~S}$ outgassing during Tharsis emplacement at the end of the Noachian seem to have been an important input of sulphur for sulphate formation and could have increased temperatures just enough to sustain liquid surface water during the Late Noachian (Halevy et al., 2007; Ehlmann et al., 2011). When volcanism subsided, $\mathrm{SO}_{2}$ was rapidly removed from the atmosphere and the temperature dropped favouring the formation of a subsurface cryosphere (Halevy et al., 2007; Carr and Head, 2010). Nonetheless, in both cases, volcanism would have been related to global warming and sulphur input during the Early Triassic and the Late Noachian occasional warm conditions (Carr and Head, 2010). In addition, acidity is enhanced by sulphide oxidation to sulphates, and later sulphate oxidation.

Petrographical features show the possible occurrence of pyrites in Lower Triassic sandstones subsequently replaced by Fe-oxides which are interbedded with APS mineral aggregates. This process would favour sulphur incorporation from pyrite to APS and, at least local, acid conditions (Galán-Abellán et al., 2013c). Fe-oxides in the Meridiani layered sediments have been related to jarosite dissolution, causing a decrease in water $\mathrm{pH}$ (Squyres and Knoll, 2005; Tosca et al., 2005).

Al solubility increases as $\mathrm{pH}$ decreases, but it is highly insoluble under moderate and circum-neutral $\mathrm{pH}$ conditions (Stumm and Morgan, 1996). A significant mobilization of $\mathrm{Al}$ has been observed in the Lower Triassic Unit, consistent with acid drainage and the alteration of detrital minerals such as illite and plagioclase, and formation of secondary phases such as kaolinite and APS minerals (Galán-Abellán et al., 2013b). In contrast, no significant Al secondary mineral phases have been detected in Martian rocks despite their predominant acidic alteration. This may be explained by low water-rock ratio conditions and preferential mineral dissolution, involving only the dissolution of olivine, but not of plagioclase, since $\mathrm{Fe}-\mathrm{Mg}$ smectites predominate over Al-rich phyllosilicates, which are more often found in acid environments (Hurowitz and McLennan, 2007; Altheide et al., 2010).

Acid conditions also favoured phosphorous dissolution of preexisting phosphate minerals. The Lower Triassic Unit is richer in phosphorus than the Upper Unit, which has been attributed to the occurrence of secondary APS minerals formed by dissolution and reprecipitation of detrital phosphate (mainly apatite, monazite and lesser proportions of xenotime), preventing the $\mathrm{P}$ leaching during the acid rock alteration (Galán-Abellán et al., 2013c; Borruel-Abadía et al., 2016). In Meridiani Planum, the $P$ source of secondary phosphates is likely weathering of the Ca-phosphates of igneous rocks (Rieder et al., 2004; Greenwood and Blake, 2006). However, phosphate phases are still not well constrained on Mars, specifically rare phosphates and sulphates, for which there is overlap between Mössbauer parameters particularly in rocks where there are multiple Febearing phases (Dyar et al., 2014).

A positive correlation exists between $\mathrm{P}$ and $\mathrm{S}$ in Lower Triassic Unit and Mars rocks. In the Triassic sandstones, $\mathrm{P}$ and $\mathrm{S}$ occur in the same mineral phase, that is, in APS, and although their distribution is heterogeneous petrographycally and geographically, they are mainly restricted to the Lower Unit (Galán-Abellán et al., 2013c). In contrast, $\mathrm{P} / \mathrm{S}$ ratios in Mars soils should be variable because of their different sources, but they are uniformly distributed indicating different diagenetic processes at the two sites. Mixing processes like aeolian homogenization coherent with the sedimentary realm of Meridiani layered deposits, or even a global acidic ocean have been proposed (Greenwood and Blake, 2006). Whereas in Triassic sandstones, APS minerals were formed in situ, in Mars they seem to be later reworked. Furthermore, the lack of available spectroscopic data on rare phosphate-sulphate means that new mineralogical compositions could be unveiled in the future in which $\mathrm{P}$ and $\mathrm{S}$ would be in the same mineral phase as those described in Triassic sandstones.

On the other hand, phosphorous is an essential biogenic element of life processes. Thus, phosphorous availability is a key point for prebiotic reactions and life origin. Phosphorous concentrations in Martian rocks and soils are several times higher than on Earth (Adcock et al., 2013; Dyar et al., 2014). Dissolved phosphorous concentrations on Earth are controlled by biological cycling and secondary mineral formation (like APS minerals), whereas on Mars, where no life evidence has been detected yet, phosphate mineral solubility would be the main mechanism of dissolved phosphate control (Greenwood and Blake, 2006).

The disappearance of APS minerals during the Middle Triassic throughout the Upper Unit indicates higher $\mathrm{pH}$ conditions and therefore low phosphorous mobilization, coinciding with a reduction in arid conditions and reappearance of fossil plant remains and tetrapod trace marks, among other signs of life (Galán-Abellán et al., 2013c; Borruel-Abadía et al., 2015). These environmental changes are associated with a major tectonic pulse affecting the European plate and recorded by a regional unconformity in several basins of the western Tethys, likely reflecting the opening of new faunal corridors and better water oxygenation, marking the beginning of life recovery during the Middle Triassic in Iberia (Bourquin et al., 2009; López-Gómez et al., 2012). On Mars, significant internal changes during the Late Noachian-Early Hesperian probably affected climate evolution and surface processes (Ruiz, 2014). Around 3.6-3.8 Ga., the ceasing of the 
Martian dynamo and magnetic field would have contributed to atmospheric erosion (Langlais et al., 2012). Besides, the reduction in the mantle convection efficiency, indicated by low heat flow values (Ruiz, 2014), could be linked to inefficient water recycling in a stagnant-lid planet (Sandu and Kiefer, 2012). Thereby, these processes would have favoured a cold arid climate and reduced the occurrence of surface liquid water, promoting phosphate dissolution and the formation of evaporitic minerals under acid conditions. This would have negative effects on possible habitability conditions for life development on Mars, just around the time (3.7 Ga.) when life arose on Earth.

Although some Earth life forms are adapted to extreme arid and acid environments (Brock, 1978; Lynn and Rocco, 2001; FernándezRemolar et al., 2005; Benison and Bowen, 2006; Amils et al., 2007), in general, extremely dry and low $\mathrm{pH}$ conditions are known to hamper and delay the development of life on Earth, as it has been observed in modern environments (Burton et al., 1985; Havens et al., 1993; NavarroGonzalez et al., 2003; Koch et al., 2012) and in ancient examples, such as the Permian-Triassic period (Kidder and Worsley, 2004; Preto et al., 2010; Benton and Newell, 2014; Chen et al., 2014). Therefore, the similarity of some Triassic habitability conditions with those described for Late Noachian-Early Hesperian Mars, suggests that the combination of general aridity, low $\mathrm{pH}$, volcanism and tectonics, among others causes, may have had negative effects on the possible development of favourable habitability settings on ancient Mars, as during the Early Triassic on Earth.

\section{Summary and Conclusions}

Non-marine Triassic rocks of the eastern Iberian Peninsula region and layered units of Meridiani Planum, in Mars, share certain features that could provide a better understanding of extreme arid, acid environments and habitability conditions (Table 1). At both sites, critical moments for life are recorded; the aftermath of the greatest biotic extinction in Earth's history and the most likely favourable conditions for life in Mars' history.

During Late Noachian-Early Hesperian period, the existence of liquid water and clay minerals probably under warmer and less acid conditions may have provided habitable conditions. Nevertheless, at the end of Noachian, an environmental switch to colder, acid and dryer conditions, reflected in mineralogical changes from clay to sulphate-predominant phases, an abrupt decrease in weathering rates and the formation of aeolian layered deposits, may have destroyed potentially habitable conditions, truncating the possible appearance and/or development of life on this planet at least in Meridiani Planum area. These critical conditions are similar to those described in eastern Iberian Peninsula during the Early Triassic associated to a delay in biotic recovery after the $\mathrm{P}-\mathrm{T}$ life crisis. In Early Triassic times, general arid and acid conditions prevailed as a consequence of the Late Permian environmental disruption that almost erased life from Earth, as shown by the occurrence of minerals formed under acid conditions, the evidence of arid sedimentological features and the extensive lack of fossil content.

However, the most important difference between these sites is that the subsequent evolution led to different environmental changes resulting on opposite habitability scenarios. The ceasing of Siberian eruptions produced a general change in the acidity of atmosphere and oceans. Although there are no direct evidences of cinerites in east Iberia, mineralogy reflects a change in the $\mathrm{pH}$ towards more favourable conditions. In addition, the break-up of Pangea during the Early-Middle Triassic led to palaeogeographical and palaeoenvironmental changes favouring biotic recovery in the $\mathrm{E}$ of Iberia. In contrast, the ceasing of Tharsis volcanism and the internal evolution of Mars may have triggered negative consequences for surface processes like atmospheric erosion or stagnation of the water cycle.

These environmental and geodynamic changes could also have a determinant influence on the processes that conditioned the availability of crucial elements for life. Although phosphorus and sulphur contents are higher on Mars than on Earth, the loss of possible habitability conditions probably played a decisive role for the organic availability of these elements and therefore hampered suitable conditions for life development during this period in this area.

In conclusion, this multidisciplinary comparison shows that despite the general differences between early Mars and Triassic Earth, they present some similar features at least in the geographical areas studied. These similarities help to further understand the conditions that may have prevented the appearance and/or development of life on Mars, and illustrates how the study of Earth analogues opens new paths in the search for suitable life conditions in other planets.

\section{Acknowledgements}

This work was supported by projects CGL2011-24048 and CGL201452699P of the Spanish Ministry of Economy, CSIC Research Group: Sistemas Sedimentarios y Variabilidad Climática (642853), and UCMBSCH-GR58/08 Projects: Análisis de Cuencas (910429) and Paleoclimas (910198). The authors thank the National Aeronautics and Space Administration (NASA) the access to Mars Images, Drs. J. LópezGómez, J. Fernández-Barrenechea, P. Suarez-Gonzalez, A. Jiménez Díaz, and R. De la Horra for their helpful comments, and also thank Ana Burton for editorial assistance. The authors are very thankful to Dr. John Bridges and another anonymous reviewer for their comments that have led to improve the manuscript.

\section{References}

Adcock, C.T., Hausrath, E.M., and Forster, P.M., 2013, Readily available phosphate from minerals in early aqueous environments on Mars. Nature Geoscience, v. 6, pp. 824-827.

Algeo, T.J., Chen, Z., Fraiser, M., and Twitchett, R.J., 2011, Terrestrialmarine teleconnections in the collapse and rebuilding of Early Triassic marine ecosystems. Palaeogeography, Palaeoclimatology, Palaeoecology, v. 308, pp. 1-11.

Altheide, T.S., Chevrier, V.F., and Noe Dobrea, E., 2010, Mineralogical characterization of acid weathered phyllosilicates with implications for secondary Martian deposits. Geochimica et Cosmochimimica Acta, v. 74, pp. 6232-6248.

Amils, R., Gonález-Toril, E., Fernández-Remolar, D., Gómez, F., Aguilera, A., Rodríguez, N., Malki, M., García-Moyano, A., Fairén, A.G., de la Fuente, V., and Sanz, J.L., 2007, Extreme environments as Mars terrestrial analogs: The Rio Tinto case. Planetary and Space Science, v. 55, pp. 370-381. 
Arche, A., and López-Gómez, J., 1996, Origin of the Permian-Triassic Iberian Basin, central-eastern Spain. Tectonophysics, v. 266, pp. 443464.

Arche, A., and López-Gómez, J., 1999a, Subsidence rates and fluvial architecture of rift-related Permian and Triassic alluvial sediments of the southeast Iberian Range, eastern Spain. Special Publications of the International Association of Sedimentologist, v. 28, pp. 283-304.

Arche, A., and López-Gómez, J., 1999b, Tectonic and geomorphic controls on the fluvial styles of the Eslida Formation, Middle Triassic, Eastern Spain. Tectonophysics, v. 315, pp. 187-207.

Arche, A., and López-Gómez, J., 2005, Sudden changes in fluvial style across the Permian-Triassic boundary in the eastern Iberian Ranges, Spain: analysis of possible causes. Palaeogeography, Palaeoclimatology, Palaeoecology, v. 229, pp. 104-126.

Arche, A., López-Gómez, J., Marzo, M., and Vargas, H., 2004, The siliciclastic Permian-Triassic deposits in Central and Northeastern Iberian Península (Iberian, Ebro and Catalan Basins): a proposal for correlation. Geológica Acta, v. 2, pp. 305-320.

Arvidson, R.E., Squyres, S.W., Bell III, J.F., Catalano, J.G., Clark, B.C., Crumpler, L.S., de Souza Jr., P.A., Fairén, A.G., Farrand, W.H., Fox, V.K., Gellert, R., Ghosh, A., Golombek, M.P., Grotzinger, J.P., Guinness, E.A., Herkenhoff, K.E., Jolliff, B.L., Knoll, A.H., Li, R., McLennan, S.M., Ming, D.W., Mittlefehldt, D.W., Moore, J.M., Morris, R.V., Murchie, S.L., Parker, T.J., Paulsen, G., Rice, J.W., Ruff, S.W., Smith, M.D., and Wolff, M.J., 2014, Ancient aqueous environments at Endeavour Crater, Mars. Science, v. 343, pp. 1248097-1-1248097-8.

Bandfield, J.L., 2002, Global mineral distributions on Mars. Journal of Geophysics Research, v. 107, pp. 9-20.

Benison, K.C., and Bowen, B.B., 2006, Acid saline lake systems give clues about past environments and the search for life on Mars. Icarus, v. 183 , pp. 225-229.

Benison, K.C., LaClair, D., and Walker, J., 2008, Physical sedimentology experiments with sulfuric acid solutions: Implications for Mars? Earth and Planetary Science Letters, v. 270, pp. 330-337.

Benton, M.J., and Newell, A.J., 2014, Impacts of global warming on Permo-Triassic terrestrial ecosystems. Gondwana Research, v. 25, pp. 1308-1337.

Benton, M.J., 2016, The Triassic. Current Biology, v. 26, pp. R1214R1218.

Béthoux, O., De La Horra, R., Benito, M.B., Barrenechea, J.M., GalánAbellán, B., and López-Gómez, J., 2009, A new triadotypomorphan insect from the Anisian (Middle Triassic), Buntsandstein facies, Spain. Journal of Iberian Geology, v. 35, pp. 179-184.

Berner, R.A., 2002, Examination of hypotheses for the Permo-Triassic boundary extinction by carbon cycle modeling. PNAS, v. 99, pp. 41724177.

Berner, R.A., 2006, GEOCARBSULF: a combined model for Phanerozoic atmospheric $\mathrm{O}_{2}$ and $\mathrm{CO}_{2}$. Geochimica et Cosmochimica Acta, v. 70, pp. 5653-5664.

Bibring, J.P., Langevin, Y., Mustard, J.F., Poulet, F., Arvidson, R., Gendrin, A., Gondet, B., Mangold, N., Pinet, P., Forget, F., and the OMEGA team, 2006, Global mineralogical and aqueous Mars history derived from OMEGA/Mars express data. Science, v. 312, pp. 400404

Bishop, J.L., Murad, E., Lane, M.D., and Mancinell, R.L., 2004, Multiple techniques for mineral identification on Mars: a study of hydrothermal rocks as potential analogues for astrobiology sites on Mars. Icarus, v. 169 , pp. 311-323.

Bishop, J.L., Loizeau, D., McKeown, N.K., Saper, L., Dyar, M.D., Des Marais, D.J., Parente, M., and Murchie, S.L., 2013, What the ancient phyllosilicates at Mawrth Vallis can tell us about possible habitability on early Mars. Planetary and Space Science, v. 86, pp.130-149.

Borruel-Abadía, V., Galán-Abellán, A.B., Kustatscher, E., Diéguez, C., López-Gómez, J., De la Horra, R., Barrenechea, J.F., and Arche, A., 2014, Palaeoenvironmental reconstruction of the early Anisian from sedimentology and plant remains in the SE Iberian Range (E Spain). Palaeogeography, Palaeoclimatology, Palaeoecology, v. 414, pp. 352 369.

Borruel-Abadía, V., López-Gómez, J., De la Horra, R., Galán-Abellán, B., Barrenechea, J.F., Arche, A., Ronchi, A., Gretter, N., and Marzo, M., 2015, Climate changes during the Early-Middle Triassic transition in the E. Iberian plate and its palaeogeographic significance in the western Tethys continental domain. Palaeogeography, Palaeoclimatology, Palaeoecology, v. 440, pp. 671-689.

Borruel-Abadía, V., Barrenechea, J.F., Galán-Abellán, A.B., AlonsoAzcárate, J., De la Horra, R., Luque, F.J., and López-Gómez, J., 2016, Quantifying aluminium-phosphate-sulphate minerals as markers of acidic conditions during the Permian-Triassic transition in the Iberian Ranges, E Spain. Chemical Geology, v. 429, pp. 10-20.

Boulouard, Ch., and Vilallard, P., 1982, Réduction ou lacune du trias inférieur sur la bordure meditérraneenne de la Chaîne Ibérique: arguments palynologiques. Comptes rendus de l'Académie des Sciences, v. 295, pp. 803-808.

Bourquin, S., Guillocheau, F., and Péron, S., 2009, Braided Rivers within an arid alluvial plain (example from the Lower Triassic, western Germanic Basin): recognition criteria and expression of stratigraphic cycles. Sedimentology, v. 56, pp. 2235-2264.

Bourquin, S., Bercovici, A., López-Gómez, J., Díez, J., Broutin, J., Ronchi, A., Durand, M., Arche, A., Bastien, L., and Amour, F., 2011, The permian-Triassic transition and the onset of Mesozoic sedimentation at the northwestern peri-Tethyan domain scale: palaeogeographic maps and geodynamic implications. Palaeogeography, Palaeoclimatology, Palaeoecology, v. 299, pp. 265-280.

Bridges, J.C., and Grady, M., 1999, A halite-siderite-anhydrite-chlorapatite assemblage in Nakhla: mineralogical evidence for evaporites on Mars. Meteoritics and Planetary Science, v. 34, pp. 407-415.

Bridges, J., 2014, Comparing clays from Mars and Earth: implications for Martian habitability. American Mineralogist, v. 99, pp. 2163-2164.

Bridges, J.C., Schwenzer, S.P., Leveille, R., Westall, F., Wiens, R.C., Mangold, N., Bristow, T., Edwards, P., and Berger, G., 2015, Diagenesis and clay mineral formation at Gale Crater, Mars. Journal of Geophysical Research, v. 120, pp. 1-19.

Brock, T.D., 1978, Thermophilic Microorganisms and Life at High Temperatures. Springer, Berlin, $466 \mathrm{p}$.

Burton, T.M., Stanford, R.M., and Allan, J.W., 1985, Acidification effects on stream biota and organic matter processing. Canadian Journal of Fisheries and Aquatic Sciences, v. 42, pp. 669-675.

Carr, M.H., 2006, The Surface of Mars: Cambridge University Press, Cambridge, $307 \mathrm{p}$.

Carr, M.H., and Head III, J.W., 2010, Geologic history of Mars. Earth and Planetary Science Letters, v. 294, pp. 185-203.

Carter, J., Loizeau, D., Mangold, N., Poulet, F., and Bibring, J.P., 2015, Widespread surface weathering on early Mars: a case for a warmer and wetter climate. Icarus, v. 248, pp. 373-382.

Chen, Z.Q., and Benton, M.J., 2012, The timing and pattern of biotic recovery following the end-Permian mass extinction. Nature Geoscience Review, v. 5, pp. 375-383.

Chen, Z.Q., Algeo, T.J., and Bottjer, D.J., 2014, Global review of the Permian-Triassic mass extinction and subsequent recovery: Part I. Earth-Science Reviews, v. 137, pp. 1-5.

Chen, Z.Q., Wang, Y., Kershaw, S., Luo, M., Yang, H., Zhao, L., Feng, Y., Chen, J., Yang, L., and Zhang, L., 2014, Early Triassic stromatolites in a siliciclastic nearshore setting in northern Perth Basin, Western Australia: geobiologic features and implications for post-extinction microbial proliferation. Global and Planetary Change, v. 121, pp. 89-100.

Christensen, P.R., and Ruff, S.W., 2004, Formation of the hematite-bearing unit in Meridiani Planum: evidence for deposition in standing water. Journal of Geophysical Research: Planets, v. 109. DOI: 10.1029/ 2003JE002233

Crhistensen, P.R., Wyatt, M.B., Glotch, T.D., Rogers, A.D., Anwar, S., 
Arvidson, R.E., Bandfield, J.L., Blaney, D.L., Budney, C., Calvin, W.M., Fallacaro, A., Fergason, R.L., Gorelick, N., Graff, T.G., Hamilton, V.E., Hayes, A.G., Johnson, J.R., Knudson, A.T., McSween Jr., H.Y., Mehall, G.L., Mehall, L.K., Moersch, J.E., Morris, R.V., Smith, M.D., Squyres, S.W., Ruff, S.W., and Wolff, M.J., 2004, Mineralogy at Meridiani Planum from the Mini-TES experiment on the Opportunity Rover. Science, v. 306, pp. 1733-1739.

Clark, B.C., Morris, R.V., McLennan, S.M., Gellert, R., Jolliff, B., Knoll, A.H., Squyres, S.W., Lowenstein, T.K., Ming, D.W., Tosca, N.J., Yen, A., Christensen, P.R., Gorevan, S., Brückner, J., Calvin, W., Dreibus, G., Farrand, W., Klngelhoefer, G., Waenke, H., Zipfel, J., Bell III, J.F., Grotzinger, J., McSween, H.Y., and Rieder, R., 2005, Chemistry and mineralogy of outcrops at Meridiani Planum. Earth and Planetary Science Letters, v. 240, pp. 73-94.

Cockell, C.S., 2014, Trajectories of Martian habitability. Astrobiology, v. 14, pp. 182-203.

Corsetti, F.A., Baud, A., Marenco, P.J., and Richoz, S., 2005, Summary of Early Triassic carbon isotope records. Comptes Rendus Palévol, v. 4, pp. 405-418.

Cui, Y., Bercovici, A., Yu, J., Kump, L.R., Freeman, K.H., Su, S., and Vajda, V., 2017, Carbon cycle perturbation expressed in terrestrial Permian-Triassic boundary sections in South China. Global and Planetary Change, v. 148, pp. 272-285.

Davies, N.S., and Gibbling, M.R., 2010, Cambrian to Devonian evolution of alluvial systems: the sedimentological impact of the earliest plants. Earth Science Reviews, v. 98, pp. 171-200.

De la Horra, R., Galán-Abellán, A.B., López-Gómez, J., Sheldon, N.D., Barrenechea, J.F., Luque F.J., Arche A., and Benito, M.I., 2012, Paleoecological and paleoenvironmental changes during the continental Midle-Late Permian transition at the SE Iberian Ranges, Spain. Global and Planetary Change, v. 94-95, pp. 46-61.

Dinarès-Turell, J., Diez, J.B., Rey, D., and Arnal, I., 2005, "Buntsandtein" magnetostratigraphy and biostratigraphic reppraisal from eastern Iberia: Early and Middle Triassic stage boundary definitions through correlation to Tethyan sections. Palaeogeography, Palaeoclimatology, Palaeoecology, v. 229, pp. 158-177.

Doubinger, J., López-Gómez, J., and Arche, A., 1990, Pollen and spores from the Permian and Triassic sediments of the Southeastern Iberian ranges, Cueva de Hierro (Cuenca) to Chelva-Manzanera (ValenciaTeruel) region, Spain. Review of Palaeobotany and Palynology, v. 66, pp. $25-45$.

Durand, M., 2006, The problem of the transition from the Permian to the Triassic series in southeastern France: comparison with other Perithetyan regions. In: Lucas, S., Cassinis, G., and Schneider, J. (Eds.), Non-Marine Permian Biostratigraphy and Biochronology. Geological Society of London, Special Publication, v. 265, pp. 281-296.

Dyar, M.D., Jawin, E.R., Breves, E., Marchand, G., Nelms, M., Lane, M.D., Mertzman, S.A., Bish, D.L., and Bishop, J.L., 2014, Mössbauer parameters of iron in phosphate minerals: implications for interpretation of Martian data. American Mineralogist, v. 99, pp. 914-942.

Edgar, L.A., Grotzinger, J.P., Hayes, A.G., Rubin, D.M., Squyres, S.W., Bell, J.F., and Herkenhoff, K.E., 2012, Stratigraphic architecture of bedrock reference section, Victoria Crater, Meridiani Planum, Mars. In: Grotzinger, J.P., and Milliken, R.E. (Eds.), Sedimentary Geology of Mars. SEPM Special Publication, v. 102, pp. 195-209.

Ehlmann, B.L., Mustard, J.F., Murchie, S.L., Bibring, J.P., Meunier, A., Fraeman, A.A., and Langevin, Y., 2011, Subsurface water and clay mineral formation during the early history of Mars. Nature, v. 479, pp. 53-60.

Erwin, D.H., 2006, Extinction. How Life on Earth Nearly Ended 250 Million Years Ago. Princenton University Press, Oxford, 296 p.

Escudero-Mozo, M.J., Márquez-Aliaga, A., Goy, A., Martín-Chivelet, J., López-Gómez, J., Márquez, L., Arche, A., Plasencia, P., Pla, C., Marzo, M., and Sánchez-Fernández, D., 2015, Middle Triassic carbonate platforms in eastern Iberia: Evolution of their fauna and palaeogeographic significance in the western Tethys. Palaeogeography, Palaeoclimatology, Palaeoecology, v. 417, pp. 236-260.

Fassett, C.I., and Head, J.W., 2008, The timing of Martian valley network activity: constraints from buffered crater counting. Icarus, v. 195, pp. 61-89.

Fernández-Remolar, D.C., Morris, R.V., Gruener, J.E., Amils, R., and Knoll, A.H., 2005, The Rio Tinto basin, Spain: Mineralogy, sedimentary geobiology, and implications for interpretation of outcrop rocks at Meridiani Planum, Mars. Earth and Planetary Science Letters, v. 240, pp. 149-167.

Flahaut, J., Carter, J., Poulet, F., Bibring, J.P., van Westrenen, W., Davies, G.R., and Murchie, S.L., 2015, Embedded clays and sulfates in Meridiani Planum, Mars. Icarus, v. 248, pp. 269-288.

Fluteau, F., Basse, J., Broutin, J., and Ramstein, G., 2003, The Late Permian climate. What can be inferred fromclimatemodeling concerning Pangea scenarios and Hercynian range altitude? Palaeogeography, Palaeoclimatology, Palaeoecology, v. 167, pp. 30-71.

Galán-Abellán, A.B., 2011, Sedimentary, mineralogical and geochemical variations in the Buntsandstein facies, Lower-Middle Triassic, of the Iberian Ranges and Catalan Coastal Ranges: implications in the recovery of the Permian-Triassic crisis. Ph.D. Thesis, Universidad Complutense, Madrid, 383 p. Available on-line: http://eprints.ucm.es/14422/1/ T33389.pdf

Galan-Abellán, A.B., Lopez-Gomez, J., Fernandez Barenechea, J.F., Marzo, M., De la Horra, R., and Arche, A., 2013a, The beginning of the Buntsandstein cycle (Early-Middle Triassic) in the Catalan Ranges, NE Spain: Sedimentary and palaeogeographic implications: Sedimentary Geology, v. 296, pp. 86-102.

Galán-Abellán, A.B., Barrenechea, J.F., Benito, M.I., De la Horra, R., Luque, F.J., Alonso-Azcárate, J., Arche, A., López-Gómez, J., and Lago, M., 2013b, Palaeoenvironmental implications of aluminium phosphate-sulphate minerals in Early-Middle Triassic continental sediments, SE Iberian Range (Spain). Sedimentary Geology, v. 289, pp.169-181.

Galán-Abellán, A.B., Alonso-Azcárate, J., Newton, R.J., Bottrell, S.H., Barrenechea, J.F., Benito, M.I., De la Horra, R., López-Gómez, J., and Luque, F.J., 2013c, Sources of Sr and S in aluminum-phosphate-sulfate minerals in early-middle Triassic sandstones (Iberian Ranges, Spain) and paleoenvironmental implications for the west Tethys. Journal of Sedimentary Research, v. 83, pp. 406-426.

Galfetti, T., Hochuli, P., Brayard, A., Bucher, H., Weissert, H., and Vigran, J.O., 2007, Smithian-Spathian boundary event: Evidence for global climatic change in the wake of the end-Permian biotic crisis. Geology, v. 35, pp. 291-294.

Gand, G., De la Horra, R., Galán-Abellán, B., López-Gómez, J., Fernández-Berrenechea, J., Arche, A., and Benito, M.I., 2010, New ichnites from the Middle Triassic of the Iberian Ranges (Spain). Pelaeoenvironmental and palaeogeographical implications: Historical Biology, v. 22, pp. $40-56$.

Geluk, M.C., and Röhling, H.G., 1999, High-resolution séquense stratigraphy of the Lower Triassic Buntsandstein: a new tool for basin análisis. In: Bachmann, G.H., and Lerche, I. (Eds.), Epicontinental Triassic. Zentralblatt fur Geologie und Paläontologie, v. 1, pp. 727-745.

Gendrin, A., Mangold, N., Bibring, J.-P., Langevin, Y., Gondet, B., Poulet, F., Bonello, G., Quantin, C., Mustard, J.F., Arvidson, R., and LeMouélic, S., 2005, Sulfates in Martian layered terrains: the OMEGA/ Mars Express view. Science, v. 307, pp. 1587-1591.

Golden, D.C., Ming, D.W., Morris, R.V., and Mertzmann, S.M., 2005, Laboratory-simulated acid-sulfate weathering of basaltic materials: Implications for formation of sulfates at Meridiani Planum and Gusev crater, Mars. Journal of Geophysical Research, v. 110. DOI: 10.1029/ 2005JE002451

Gómez, F., Rodríguez-Manfredi, J.A., Rodríguez, N., Fernández-Sampedro, M., Caballero-Castrejón, F.J., and Amils, R., 2012, Habitability: Where to look for life? Halophilic habitats: Earth analogs to study 
Mars habitability. Planetary and Space Science, v. 68, pp. 48-55.

Greenberger, R.N., Mustard, J.F., Cloutis, E.A., Pratt, L.M., Saber, P.E., Mann, P., Turner, K., Dyar, M.D., and Bish, D.L., 2015, Serpentinization, iron oxidation, and aqueous conditions in an ophiolite: implications for hydrogen production and habitability on Mars. Earth and Planetary Science Letters, v. 15, pp. 21-34.

Greenwood, J.P. and Blake, R.E., 2006, Evidence for an acidic ocean on Mars from phosphorus geochemistry of Martian soils and rocks. Geology, v. 34, pp. 953-956.

Grotzinger, J.P., Arvidson, R.E., Bell III, J.F., Calvin, W., Clark, B.C., Fike, D.A., Golombek, M., Greeley, R., Haldemann, A., Herkenhoff, K.E., Jolliff, B.L., Knoll, A.H., Malin, M., McLennan, S.M., Parker, T., Soderblom, L., Sohl-Dickstein, J.N., Squyres, S.W., Tosca, N.J., and Watters, W.A., 2005, Stratigraphy and sedimentology of a dry to wet eolian depositional system, Burns formation, Meridiani Planum, Mars. Earth and Planetary Science Letters, v. 240, pp. 11-72.

Grotzinger, J.P., Crisp, J.A., Vasavada, A.R., and MSL Science Team, 2015, Curiosity's mission of exploration at Gale Crater, Mars. Elements, v. 11, pp. 19-26.

Guidry, M.W., and Mackenzie, F.T., 2003, Experimental study of igneous and sedimentary apatite dissolution: control of $\mathrm{pH}$, distance from equilibrium, and temperature on dissolution rates. Geochimica et Cosmochimica Acta, v. 67, pp. 2949-2963.

Halevy, I., Zuber, M.T., and Schrag, D.P., 2007, A sulfur dioxide climate feedback on early Mars. Science, v. 318, pp. 1903-1907.

Havens, K.E., Yan, N.D., and Keller, W., 1993, Lake acidification: effects on crustacean zooplankton populations. Environmental Science and Technology, v. 27, pp. 1621-1624.

Hayes, A.G., Grotzinger, J.P., Edgar, L.A., Squyres, S.W., Watters, W.A., and Sohl-Dickstein, J., 2011, Reconstruction of eolian bed forms and paleocurrents from cross-bedded strata at Victoria Crater, Meridiani Planum, Mars. Journal of Geophysical Research, v. 116, pp. 1-17.

Herkenhoff, K.E., Squyres, S.W., Arvidson, R., Bass, D.S., Bell III, J.F., Bertelsen, P., Ehlmann, B.L., Farrand, W., Gaddis, L., Greeley, R., Grotzinger, J., Hayes, A.G., Hviid, S.F., Johnson, J.R., Jolliff, B., Kinch, K.M., Knoll, A.H., Madsen, M.B., Maki, J.N., McLennan, S.M., McSween, H.Y., Ming, D.W., Rice, J.W. Jr., Richter, L., Sims, M., Smith, P.H., Soderblom, L.A., Spanovich, N., Sullivan, R., Thompson, S., Wdowiak, T., Weitz, C., and Whelley, P., 2004, Evidence from opportunity's Microscopic Imager for water on Meridiani Planum. Science, v. 306, pp. 1723-1726.

Hoefen, T.M., Clark, R.N., Bandfield, J.L., Smith, M.D., Pearl, J.C., and Christensen, P.R., 2003, Discovery of olivine in the Nili Fossae Region of Mars. Science, v. 302, pp. 627-630.

Hurowitz, J.A., and McLennan, S.M., 2007, A $\sim 3.5$ Ga record of waterlimited, acidic weathering conditions on Mars. Earth and Planetary Science Letters, v. 260, pp. 432-443

Hurowitz, J.A., McLennan, S.M., Lindsley, D.H., and Schoonen, M.A.A., 2005, Experimental epithermal alteration of synthetic Los Angeles meteorite: implications for the origin of Martian soils and the identification of hydrothermal sites on Mars. Journal of Geophysical Research, v. 110. DOI: 10.1029/2004JE002391

Hurowitz, J.A., McLennan, S.M., Tosca, N.J., Arvidson, R.E., Michalski, J.R., Ming, D.W., Schöder, C., and Squyres, S.W., 2006, In-situ and experimental evidence for acidic weathering on Mars. Journal of Geophysical Research, v. 111. DOI: 10.1029/2005JE002515.

Hynek, B.M., and Phillips, R.J., 2008, The stratigraphy of Meridiani pLanyum, Mars, and implications for the layered deposits' origin. Earth and Planetary Science Letters, v. 274, pp. 214-220.

Hynek, B.M., Arvidson, R.E., and Phillips, R.J., 2002, Geologic setting and origin of Terra Meridiani hematite deposit on Mars. Journal of Geophysical Research, v. 107. DOI: 10.1029/2002JE001891

Jaumann, R., Tirsch, D., Hauber, E., Erkeling, G., Hiesinger, H., Le Deit, L., Sowe, M., Adeli, S., Petau, A., and Reiss, D., 2013, Water and Martian habitability: results of an integrative study of water related pro- cesses on Mars in context with an interdisciplinary Helmholtz research alliance "Planetary Evolution and Life". Planetary and Space Science, v. 98 , pp. 128-145.

Javaux, E.J., and Dehant, V., 2010, Habitability: from stars to cells. The Astronomy and Astrophysics Review, v. 18, pp. 383-416.

Johnson, S.S., Mischna, M.A., Grove, T.L., and Zuber, M.T., 2008, Sulfurinduced greenhouse warming on early Mars. Journal of Geophysical Research, v. 113, pp. 1-15.

Karunatillake, S., Wray, J.J., Gasnault, O., McLennan, S.M., Rogers, A.D., Squyres, S.W., Boynton, W.V., Skok, J.R., Ojha, L., and Olsen, N., 2014, Sulfates hydrating bulk soil in the Martian low and middle latitudes. Geophysical Research Letters, v. 41, pp. 7987-7996.

Kearsey, T., Twitchett, R.J., Price, G.D., and Grimes, S.T., 2009, Isotope excursions and palaeotemperature estimates from the Permian/Triassic boundary in the Southern Alps (Italy). Palaeogeography, Palaeoclimatology, Palaeoecology, v. 279, pp. 29-40.

Kidder, D.L., and Worsley, T.R., 2004, Causes and consecuences of extreme Permo-Triassic warming to globally equable climate and relation to the Permo-Triassic extinction and recovery. Palaeogeography, Palaeoclimatology, Palaeoecology, v. 203, pp. 207-237.

KlingelHöfer, G., Morris, R.V., Bernhardt, B., Schröder, C., Rodionov, D.S., de Souza Jr., P.A., Yen, A., Gellert, R., Evlanov, E.N., Zubkov, B., Foh, J., Bonnes, U., Kankeleit, E., Gütlich, P., Ming, D.W., Renz, F., Wdowiak, T., Squyres, S.W., and, Arvidson, R.E., 2004, Jarosite and hematite at Meridiani Planum from Opportunity's Mössbauer spectrometer. Science, v. 306, pp. 1740-1745.

Knoll, A.H., Carr, M., Clark, B., Des Marais, D.J., Farmer, J.D., Fischer, W.W., Grotzinger, J.P., McLennan, S.M., Malin, M., Schröder, C., Squyres, S., Tosca, N.J., and Wdowiak, T., 2005, An astrobiological perspective on Meridiani Planum. Earth and Planetary Science Letters, v. 240, pp. 179-189.

Knoll, A.H., and Grotzinger, J., 2006, Water on Mars and the prospect of Martian life. Elements, v. 21, pp. 69-173.

Knoll, A.H., Bambach, R.K., Payne, J.L., Pruss, S., and Woodward, W.F., 2007, Paleophysiology and end-Permian mass extinction. Earth and Planetary Science Letters, v. 256, pp. 295-313.

Koch, M., Bowes, G., Ross, C., and Zhang, X., 2012, Climate change and ocean acidification effects on seagrasses and marine macroalgae. Global change Biology, v. 19, pp. 103-132.

Korte, C., Kozur, H.W., Bruckschein, P., and Veizer, J., 2003, Strontium Isotope evolution of Late Permian and Triassic seawater. Geochimica et Cosmochimica Acta, v. 67, pp. 47-62.

Kozur, H.W., and Weems, R.E., 2011, Detailed correlation and age of continental late Changhsingian and earliest Triassic beds: implications for the role of the Siberia trap in the Permian-Triassic biotic crisis. Palaeogeography, Palaeoclimatology, Palaeoecology, v. 308, pp. 22-40.

Lammer, H., Chassefière, E., Karatekin, Ö., Morschhauser, A., Niles, P.B., Mousis, O., Odert, P., Möstl, U.V., Breuer, D., Dehant, V., Grott, M., Gröller, H., Hauber, E., and San Pham, L.B., 2013, Outgassing history and escape of the Martian atmosphere and water inventory. Space Science Reviews, v. 174, pp. 113-154.

Lane, M.D., Christensen, P.R., and Hartmann, W.K., 2003, Utilization of the THEMIS visible and infrared imaging data for crater population studies of the Meridiani Planum landing site. Geophysical Research Letters, v. 30, p. 1770.

Langlais, B., Thébault, E., Ostanciaux, E., and Mangold, N., 2012, A late Martian dynamo cessation time 3.77 Gy ago. LPI Contributions, v. 1680, p. 7067.

Léveillé, R.J., Bridges, J., Wiens, R.C., Mangold, N., Cousin, A., Lanza, N., Forni, O., Ollila, A., Grotzinger, J., Clegg, S., Siebach, K., Berger, G., Clark, B., Fabre, C., Anderson, R., Gasnault, O., Blaney, D., De Flores, L., Leshin, L., Maurice, S., and Newsom, H., 2014, Chemistry of fracture-filling raised ridges in Yellowknife Bay, Gale Crater: window into past aqueous activity and habitability on Mars. Journal of Geophysical Research Planets, v. 119, pp. 2398-2415. 
López-Gómez, J., and Arche, A., 1992a, Las unidades litoestratigráficas del Pérmico y Triásico inferior y medio en el sector de la Cordillera Ibérica. Estudios Geológicos, v. 48, pp. 123-143.

López-Gómez, J., and Arche, A., 1992b, Paleogeographical significance of the Röt (Anisian, Triassic) Facies (Marines clays, muds and marls Fm.) in the Iberian Ranges, eastern Spain. Palaeogeography, Palaeoclimatology, Palaeoecology, v. 91, pp. 347-361.

López-Gómez, J., Arche, A., and Pérez-López, A., 2002, Permian and Triassic. In: Gibbons, W., and Moreno, T. (Eds.), The Geology of Spain. The Geological Society of London, pp. 185-221.

López-Gómez, J., Galán-Abellán, A.B., De la Horra, R., Barrenechea, J.F., Arche, A., Bourquin, S., Marzo, M., and Durand, M., 2012, Sedimentary evolution of the continental Early-Middle Cañizar Formation (Central Spain): implications for life recovery after the Permian-Triassic crisis. Sedimentary Geology, v. 249-250, pp. 26-44.

Lynn, J.R., and Rocco, L.M., 2001, Life in extreme environments. Nature, v. 409, pp. 1092-1101.

Madden, M.E.E., Bodnar, R.J., and Rimstidt, J.D., 2004, Jarosite as an indicator of water-limited chemical weathering on Mars. Nature, v. 431, pp. 821-823.

Marfil, R., La Iglesia, A., and Estupiñan, J., 2013, Origin and nature of the aluminium phosphate-sulfate minerals (APS) associated with uranium mineralization in Triassic red-beds (Iberian Range, Spain). Estudios Geológicos, v. 69, pp. 21-34.

Martinez-Frias, J., Amaral, G., and Vázquez, L., 2007, Astrobiological significance of minerals on Mars surface environment. In: Amils, R., Ellis-Evans, C., and Hinghofer-Szalkay, H.G. (Eds.), Life in Extreme Environments. Springer, pp. 55-67.

Martínez-Frías, J., 2014, Search for life on Mars: an astrogeological approach. In: Kolb, V. (Ed.), Astrobiology: An Evolutionary Approach. CRC Press, pp. 301-323.

Maruoka, T., Koeberl, C., Hancox, P.J., and Reimold, W.U., 2003, Sulphur geochemistry across a terrestrial Permian-Triassic boundary section in the Karoo Basin, South Africa. Earth and Planetary Science Letters, v. 206, pp. 101-117.

Marzo, M., 1980, El Buntsandstein de los Catalánides: Estratigrafía y procesos de sedimentación. Ph.D. Thesis, Universidad de Barcelona, Barcelona, $317 \mathrm{p}$.

Marzo, M., 1986, Secuencias fluvio-eólicas en el buntsandstein del Macizo de Garraf (Provincia de Barcelona). Cuadernos de Geología Ibérica, v. 10, pp. 207-233.

McCollom, T.M., and Hynek, B.M., 2005, A volcanic environment for bedrock diagenesis at Meridiani Planum on Mars. Nature, v. 438, pp. 1129-1131.

McLennan, S.M., Bell III, J.F., Calvin, W.M., Christensen, P.R., Clark, B.C., de Souza, P.A., Farmer, J., Farrand, W.H., Fike, D.A., Gellert, R., Ghosh, A., Glotch, T.D., Grotzinger, J.P., Hahn, B., Herkenhoff, K.E., Hurowitz, J.A., Johnson, J.R., Johnson, S.S., Jolliff, B., Klingenlhöfer, G., Knoll, A.H., Learner, Z., Malin, M.C., McSween Jr., H.Y., Pocock, J., Ruff, S.W., Soderblom, L.A., Squyres, S.W., Tosca, N.J., Watters, W.A., Wyatt, M.B., and Yen, A., 2005, Provenance and diagenesis of the evaporite-bearing Burns formation, Meridiani Planum, Mars. Earth and Planetary Science Letters, v. 240, pp. 95-121.

McLennan, S.M., 2012, Geochemistry of sedimentary processes on Mars. In: Grotzinger, J.P., and Milliken, R.E. (Eds.), Sedimentary Geology of Mars. SEPM Special Publication, v. 102, pp. 119-138.

Michalski, J.R., Cuadros, J., Niles, P.B., Parnell, J., Rogers, A.D., and Wright, S.P., 2013, Groundwater activity on Mars and implications for a deep biosphere. Nature Geoscience, v. 6, pp. 133-138.

Montañez, I., Tabor, N., Niemeier, D., DiMichele, W., Frank, T.D., Fielding, C.R., Isbell, J., Birgenheier, L.P., and Rygel, M.C., 2007, $\mathrm{CO}_{2-}$ Forced climate and vegetation instability during Late Paleozoic deglaciation. Science, v. 315, pp. 87-89.

Morris, R.V., Ming, D.W., Graff, T.G., Arvidson, R.E., Bell III, J.F., Squyres, S.W., Mertzman, S.A., Gruener, J.E., Golden, D.C., Le, L., and Robinson, G.A., 2005, Hematite spherules in basaltic tephra altered under aqueous, acid-sulfate conditions on Mauna Kea volcano, Hawaii: Possible clues for the occurrence of hematite-rich spherules in the Burns formation at Meridiani Planum, Mars. Earth and Planetary Science Letters, v. 240, pp. 168-178.

Murchie, S.L., Mustard, J.F., Ehlmann, B.L., Milliken, R.E., Bishop, J.L., McKeown, N.K., Noe Dobrea, E.Z., Seelos, F.P., Bucxkowski, D.L., Wiseman, S.M., Arvidson, R.E., Wray, J.J., Swayze, G., Clark, R.N., Des Marais, D.J., McEwen, A.S., and Bibring, J-P., 2009, A synthesis of Martian aqueous mineralogy after 1 Mars year of observations from the Mars Reconnaissance Orbiter. Journal of Geophysical Research, v. 114. DOI: $10.1029 / 2009 J E 003342$

Navarro-Gonzalez, R., Rainey, F.A., Molina, P., Bagaley, D.R., Hollen, B.J., De la Rosa, J., Small, A.M., Quinn, R.C., Grunthaner F.J., Cáceres, L., Gómez-Silva, B., and McKay, C.P., 2003, Mars-like soils in the Atacama Desert, Chile, and the dry limit of microbial life. Science, v. 302, pp. 1018-1021.

Nesbitt, H.W., and Wilson, H.W., 1992, Recent chemical weathering of basalts. American Journal of Science, v. 292, pp. 740-777.

Nikishin, A.M., Ziegler, P.A., Abbott, D., Brunet, M.-F., and Cloetingh, S., 2002, Permo-Triassic intraplate magmatism and rifting in Eurasia: implications for mantle plumes and mantle dynamics. Tectonophysics, v. 351, pp. 3-39.

Payne, J.L., and Kump, L.R., 2007, Evidence for recurrent Early Triassic massive volcanism from quantitative interpretation of carbon isotope fluctuations. Earth and Planetary Science Letters, v. 256, pp. 264-277.

Péron, S., Bourquin, S., Fluteau, F., and Guillocheau, F., 2005, Paleoenvironment reconstruction and climate simulations of the Early Triassic: impact of the water and sediment supply on the preservation of fluvial system. Geodinamica Acta, v. 18, pp. 431-446.

Preto, N., Kustatscher, E., and Wignall, P.B., 2010, Triassic climates state of the art and perspectives. Palaeogeography, Palaeoclimatology, Palaeoecology, v. 290, pp. 1-10.

Preston, L.J., and Dartnell, L.R., 2014, Planetary habitability: lessons learned from terrestrial analogues. International Journal of Astrobiology, v. 13, pp. 81-98.

Prokoph, A., Shields, G.A., and Veizer, J., 2008, Compilation and timeseries analysis of a marine carbonate $\delta^{18} \mathrm{O}, \delta^{13} \mathrm{C},{ }^{87} \mathrm{Sr} /{ }^{86} \mathrm{Sr}$ and $\delta^{34} \mathrm{~S}$ database through Earth history. Earth-Science Reviews, v. 87, pp. 113-133.

Rieder, R., Gellert, R., Anderson, R.C., Brückner, J., Clark, B.C., Dreibus, G., Economou, T., Klingelhöfer, G., Lugmair, G.W., Ming, D.W., Squyres, S.W., d'Uston, C., Wänke, H., Yen, A., and Zipfel, J., 2004, Chemistry of rocks and soils at Meridiani Planum from the alpha particle X-ray spectrometer. Science, v. 306, pp. 1746-1749.

Roach, L.H., Mustard, J.F., Lane, M.D., Bishop, J.L., and Murchie, S.L., 2010, Diagenetic hematite and sulfate assemblages in Valles Marineris. Icarus, v. 207, pp. 659-674.

Röling, W.F., Aerts, J.W., Patty, C.H., ten Kate, I.L., Ehrenfreund, P., and Direito, S.O., 2015, The significance of microbe-mineral-biomarker interactions in the detection of life on Mars and beyond. Astrobiology, v. 15, pp. 492-507.

Romano, C., Goudemand, N., Vennemann, T.W., Ware, D., SchneebeliHermann, E., Hochuli, P.A., Binkmann, W., and Bucher, H., 2013, Climatic and biotic upheavals following the end-permian mass extinction. Nature Geoscience, v. 6, pp. 57-60.

Ruiz, J., 2014, The early heat loss evolution of Mars and their implications for internal environmental history. Scientific Reports, v. 4. DOI: 10.1038/ srep04338

Sánchez-Martínez, S., de la Horra, R., Arenas, R., Gerdes, A., GalánAbellán, A., López-Gómez, J., Barrenechea, J., and Arche, A., 2012, $\mathrm{U}-\mathrm{Pb}$ ages of detrital zircons from the Permo-Triassic series of the Iberian Ranges: a record of variable provenance during rift propagation. The Journal of Geology, v. 120, pp. 135-154.

Sandu, C., and Kiefer, W.S., 2012, Degassing history of Mars and the lifespan of its magnetic dynamo. Geophysical Research Letters, v. 39. DOI: 


\subsection{9/2011GL050225}

Sanson-Barrera, A., Hochuli, P.A., Bucher, H., Schneebeli-Hermann, E., Weissert, H., Thierry, A., and Bernasconi, S.M., 2015, Late Permianearliest Triassic high-resolution organic carbon isotope and palynofacies records from Kap Stosch (East Greenland). Global and Planetary Change, v. 133, pp. 149-166.

Schwenzer, S.P., Bridges, J.C., Wiens, R.C., Conrad, P.G., Kelley, S.P., Leveille, R., Mangold, N., Martin-Torres, J., McAdam, A., Newsom, H., Zorzanpo, M.P., Rapin, W., Spray, J., Treiman, A.H., Westall, F., Fairen, A.G., and Meslin, P.-Y., 2016, Fluids during diagenesis and sulfate vein formation in sediments at Gale Crater, Mars. Meteoritics and Planetary Science, v. 51, pp. 2175-2202.

Sephton, M.A, Jiao, D., Engel, M.H., Looy, C.V., and Visscher, H., 2015, Terrestrial acidification during the end-Permian biosphere crisis? Geology, v. 43, pp. 159-162.

Shen, J., Schoepfer, S.D., Feng, Q., Zhou, L., Yu, J., Song, H., Wei, H., and Algeo, T.J., 2014, Marine productivity changes during the end-Permian crisis and Early Triassic recovery. Earth-Science Reviews, v. 149, pp. 136-162.

Squyres, S.W., and Kasting, J.F., 1994, Early Mars: How warm and how wet? Science, v. 265, pp. 744-749.

Squyres, S.W., and Knoll, A.H., 2005, Sedimentary rocks at Meridiani Planum: origin, diagenesis, and implications for life on Mars. Earth and Planetary Science Letters, v. 240, pp. 1-10.

Squyres, S.W., Grotzinger, J.P., Arvidson, R.E., Bell III, J.F., Calvin, W., Christensen, P.R., Clark, B.C., Crisp, J.A., Farrand, W.H., Herkenhoff, K.E., Johnson, J.R., Klingelhöfer, G., Knoll, A.H., McLennan, S.M., McSween Jr., H.Y., Morris, R.V., Rice Jr., J.W., Rieder, R., and Soderblom, L.A., 2004, In situ evidence for an ancient aqueous environment at Meridiani Planum, Mars. Science, v. 306, pp. 1709-1714.

Squyres, S.W., Knoll, A.H., Arvidson, R.E., Clark, B.C., Grotzinger, J.P., Jolliff, B.L., McLennan, S.M., Tosca, N., Bell III, J.F., Calvin, W.M., Farrand, W.H., Glotch, T.D., Golombek, M.P., Herkenhoff, K.E., Johnson, J.R., Klingelhöfer, G., McSween, H.Y., and Yen, A.S., 2006, Two years at Meridiani Planum: results from the Opportunity Rover. Science, v. 313, pp. 1403-1407.

Squyres, S.W., Knoll, A.H., Arvidson, R.E., Ashley, J.W., Bell III, J.F., Calvin, W.M., Chrsitensen, P.R., Clark, B.C., Cohen, B.A., De Souza Jr., P.A., Edgar, L., Farrand, W.H., Fleischer, I., Gellert, R., Golombek, M.P., Grant, J., Grotzinger, J., Hayes, A., Herkenhoff, K.E., Johnson, J.R., Jolliff, B., Klingelhöfer, G., Knudson, A., Li, R., McCoy, T.J., McLennan, S.M., Ming, D.W., Mittlefehldt, D.W., Morris, R.V., Rice, Jr., J.W., Schröder, C., Sullvian, R.J., Yen, A., and Yingst, R.A., 2009, Exploration of Victoria Crater by the Mars rover Opportunity. Science, v. 324, pp.1058-1061.

Squyres, S.W., Arvidson, R.E., Bell III, J.F., Calef III, F., Clark, B.C., Cohen, B.A., Crumpler, L.A., de Souza, Jr., P.A., Farrand, W.H., Gellert, R., Grant, J., Herkenhoff, K.E., Hurowitz, J.A., Johnson, J.R., Jolliff, B.L., Knoll, A.H., Li, R., McLennan, S.M., Ming, D.W., Mittlefehldt, D.W., Parker, T.J., Paulsen, G., Rice, M.S., Ruff, S.W., Schröder, C., Yen, A.S., and Zacny, K., 2012, Ancient impact and aqueous processes at Endeavour Crater, Mars. Science, v. 336, pp. 570-576.

Steele, A., Beaty, D.W., Amend, J., Anderson, R., Beegle, L, Benning, L, Bhattacharya, J., Blake, D., Brinckerhoff, W., Biddle, J., Cady, S., Conrad, P., Lindsay, J., Mancinelli, R., Mungas, G., Mustard, J., Oxnevad, K.,
Toporski, J., and Waite, H., 2005, The astrobiology field laboratory. unpublished white paper, 72 p, posted Dec., 2005 by the Mars Exploration Program Analysis Group (MEPAG) at http://mepag.jpl.nasa.gov/reports/ index.html

Stromberg, J.M., Applin, D.M., Cloutis, E.A., Rice, M., Berard, G., and Mann, P., 2014, The persistence of a chlorophyll spectral biosignature from Martian evaporite and spring analogues under Mars-like conditions. International Journal of Astrobiology, v. 13, pp. 203-223.

Stumm, W., and Morgan, J.J., 1996, Aquatic Chemistry: Chemical Equilibria and Rates in Natural Waters. John Wiley \& Sons, New York. 1022 p.

Tosca, N.J., and McLennan, S.M., 2006, Chemical divides and evaporate assemblages on Mars. Earth and Planetary Science Letters, v. 241, pp. $21-31$.

Tosca, N.J., McLennan, S.M., Clark, B.C., Grotzinger, J.P., Hurowtiz, J.A., Knoll, A.H., Schröder, C., and Squyres, S.W., 2005, Geochemical modeling of evaporation processes on Mars: insight from the sedimentary record at Meridiani Planum. Earth and Planetary Science Letters, v. 240 , pp. $122-148$.

Tosca, N.J., McLennan, S.M., Dyar, M.D., Sklute E.C., and Michael F.M., 2008, Fe oxidation processes at Meridiani Planum and implications for secondary Fe mineralogy on Mars. Journal of Geophysical Research: Planets, v.113. DOI: 10.1029/2007JE003019

Tu, V.M., Hausrath, E.M., Tschauner, O., Iota, V., and Egeland, G.W., 2014, Dissolution rates of amorphous Al- and Fe-phosphates and their relevance to phosphate mobility on Mars. American Mineralogist, v. 99, pp. 1206-1215.

Vargas, H., Gaspar-Escribano, J., López-Gómez, J., van Wees, J-D., Cloetingh, S., De la Horra, R., and Arche, A., 2009, A comparison of the Iberian and Ebro Basins during the Permian and Triassic, eastern Spain: a quantitative subsidence modelling approach. Tectonophysics, v. 474, pp. 160-183.

Westall, F., Loizeau, D., Foucher, F., Bost, N., Betrand, M., Vago, J., and Kminek, G., 2013, Habitability on Mars from a microbial point of view. Astrobiology, v. 13, pp. 887-897.

Wignall, P.B., 2001, Large igneous provinces and mass extinctions. EarthScience Review, v. 53, pp. 1-33.

Williams, R.M., and Phillips, R.J., 2001, Martian valley network morphology. $31^{\text {st }}$ Lunar and Planetary Science Conference, 2001, Lunar and Planetary Institute, v. 31, p. 1912.

Woods, A.D., 2005, Paleoceanographic and paleoclimatic context of Early Triassic time. Comptes Rendus Palévol, v. 4, pp. 395-404.

Wray, J.J., Noe Dobrea, E.Z., Arvidson, R.E., Wiseman, S.M., Squyres, S.W., McEwen, A.S., Mustard, J.F., and Murchie, S.L., 2009, Phyllosilicates and sulfates at Endeavour Crater, Meridiani Planum. Geophysical Research Letters, v. 36. DOI: 10.1029/2009GL040734

Wyatt, M.B., McSween, H.Y., Tanaka, K.L., and Head, J.W., 2004, Global geologic context for rock types and surface alteration on Mars. Geology, v. 32, pp. 645-648.

Young, G.M., and Nesbitt, H.W., 1998, Processes controlling the distribution of $\mathrm{Ti}$ and $\mathrm{Al}$ in weathering profiles, siliciclastic sediments and sedimentary rocks. Journal of Sedimentary Research, v. 68, pp. 448-455.

Zolotov, M.Y., and Mironenko, M.V., 2007, Timing of acid weathering on Mars: a kinetic-thermodynamic assessment. Journal of Geophysical Research, v. 112. DOI: 10.1029/2006JE002882 


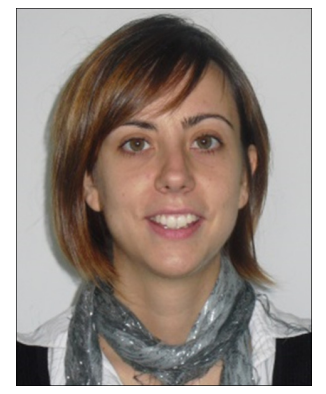

Ana Belén Galán-Abellán is a researcher in the Geology Faculty of the Complutense University of Madrid (UCM), for her PhD she conducted a multidisciplinary approach to paleoenvironmental proxies of life-recovery after the Permian-Triassic extinction. Her work was awarded the extraordinary $\mathrm{PhD}$ award of the Geology Faculty (UCM) in 2011. She has participated in more than 12 research projects collaborating with other institutions, such as the Zaragoza University, the Geochemistry of Sulphide Laboratory of Leeds and The Steinmann Institute of the Bonn University, resulting in many SCI publications, international meeting communications and coorganized international field-trips. She is member of the Spanish Planetology and Astrobiology Network (REDESPA).

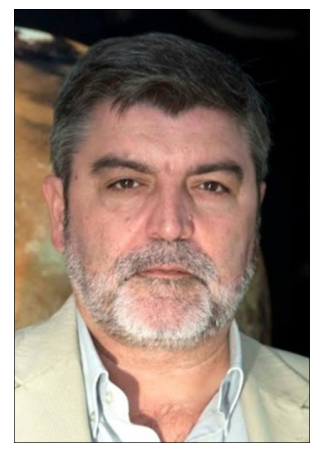

Jesús Martinez Frías is a scientific Researcher at IGEO (CSIC-UCM) and director of the Spanish Planetology and Astrobiology Network. More than 40 projects and scientific campaigns (e.g.., Antarctica, Mauritania, Iceland). In 2002, he participated in the NASA flight to study the Leonid Meteor Shower. He is co-I in NASA-MSL, ESA-ExoMars and NASA-Mars2020. He has published 8 books and more than 200 articles (Science, Nature, Geology, Episodes, etc.). Former Member of the UN ECOSOC Committee on Natural Resources, Ex-ViceChair of the UNCSTD and Ex-Chair of the IUGS-COGE. He is President of the IAGETH. He has received several awards and recognitions (NASA, ESA, GSAf, ArabGU). 